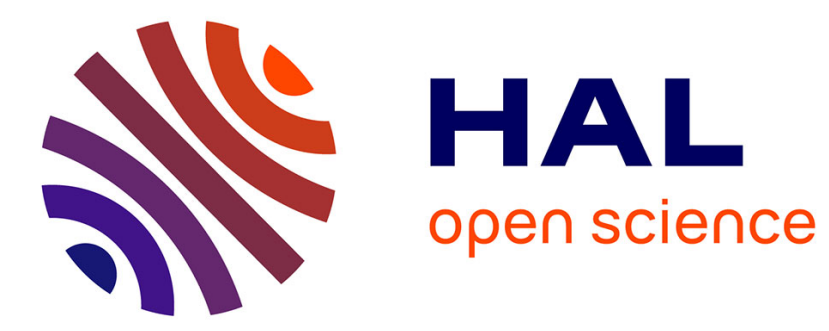

\title{
Effect of fine particles on the hydraulic behavior of interlayer soil in railway substructure
}

Trong Vinh Duong, Yu-Jun Cui, Anh Minh A.M. Tang, Jean Claude Dupla, Nicolas Calon

\section{- To cite this version:}

Trong Vinh Duong, Yu-Jun Cui, Anh Minh A.M. Tang, Jean Claude Dupla, Nicolas Calon. Effect of fine particles on the hydraulic behavior of interlayer soil in railway substructure. Canadian Geotechnical Journal, 2014, 51 (7), pp.735-746. 10.1139/cgj-2013-0170 hal-01111160

\section{HAL Id: hal-01111160 \\ https://hal-enpc.archives-ouvertes.fr/hal-01111160}

Submitted on 25 Apr 2018

HAL is a multi-disciplinary open access archive for the deposit and dissemination of scientific research documents, whether they are published or not. The documents may come from teaching and research institutions in France or abroad, or from public or private research centers.
L'archive ouverte pluridisciplinaire HAL, est destinée au dépôt et à la diffusion de documents scientifiques de niveau recherche, publiés ou non, émanant des établissements d'enseignement et de recherche français ou étrangers, des laboratoires publics ou privés. 
1 Effect of fine particles on the hydraulic behavior of interlayer

2 soil in railway substructure

3 Trong Vinh DUONG ${ }^{1}$, Yu-Jun CUI ${ }^{1}$, Anh Minh TANG $^{1}$, Jean-Claude DUPLA ${ }^{1}$, Nicolas

4 CALON $^{2}$

$5 \quad{ }^{1}$ Ecole des Ponts Paris Tech (ENPC), Laboratoire Navier/CERMES

$6 \quad{ }^{2}$ French Railway Company $(S N C F)$

7

8

9 Corresponding author:

10 Prof. Yu-Jun CUI

11 Ecole des Ponts ParisTech

12 6-8 av. Blaise Pascal, Cité Descartes, Champs-sur-Marne

13 F-77455 MARNE LA VALLEE - France

14 Telephone : +33164153550

15 Fax : +33164153562

16 E-mail : yujun.cui@enpc.fr 


\section{Abstract:}

18 The ancient railway substructure in France was built by emplacing ballast directly on sub-grade.

19 Over years of operation, the inter-penetration of ballast and sub-grade created a soil layer

20 between them. Under different conditions, this naturally formed layer, namely interlayer, can

21 contain different quantities of fine particles, becoming more or less sensitive to changes in water

22 content. As the water content changes are governed by the hydraulic behavior of interlayer soil,

23 assessing the influence of fine particles content on the hydraulic behavior of interlayer soil is

24 important. To this end, the hydraulic behavior of an interlayer soil taken from Sénissiat (near

25 Lyon, France) was investigated using two infiltration columns, a large-scale column equipped

26 with tensiometers and TDR for suction and volumetric water content measurements, respectively,

27 and a smaller column equipped with high capacity tensiometers only. Different fines contents

28 were considered and wetting-drying cycles were applied to the soil specimens. The hydraulic

29 conductivity was determined by applying the instantaneous profile method. The results obtained

30 showed that i) hysteresis exists for both the soil water retention curve and the hydraulic

31 conductivity changes with suction; ii) the effect of wetting-drying cycles is insignificant; iii)

32 adding $10 \%$ of fine particles to the natural interlayer soil changes the soil water retention curve

33 but does not induce significant changes in hydraulic conductivity; iv) the hydraulic conductivity

34 of interlayer soil with $10 \%$ of fine particles added is close to that of soil sieved at $2 \mathrm{~mm}$,

35 suggesting that the hydraulic conductivity of interlayer soil is mainly governed by fine particles

36 through suction effect.

37 Keywords: railway substructure; interlayer soil; fines content; instantaneous profiles method;

38 hydraulic conductivity. 
41 Many railway lines over the world have been in operation for more than one hundred years. In

42 France, the ancient lines represent $94 \%$ of the whole railway network. As opposed to the new

43 lines, the ancient ones were constructed by direct installation of ballast onto sub-grade without

44 any separation layer. Over years of operation and with the increasing traffic, load, and speed of

45 train, there are more and more problems related to the stability, loss of strength of substructure. A

46 number of studies have been conducted to assess the state of substructure and to develop

47 adequate maintenance methods (Trinh 2011; Duong et al. 2013; Cui et al. 2013). It was found

48 that one of the particularities of ancient substructure is the presence of a soil layer namely

49 interlayer that has been created mainly by interpenetration of ballast and fine particles of sub-

50 grade.

In France, it has been decided recently to renew the ancient railway network. During the

52 renewal, the interlayer will be kept as part of the substructure thanks to its high mechanical

53 resistance related to its high dry unit mass $\left(2.4 \mathrm{Mg} / \mathrm{m}^{3}\right.$ at the Sénissiat site, according to Trinh et

54 al. 2011) reached by natural dynamic compaction corresponding to the circulation of trains.

55 However, the mechanical behavior of interlayer soil can show a large variability, depending on

56 the proportion of fine particles contained in it. A number of studies (Babic et al. 2000; Pedro

57 2004; Naeini and Baziar 2004; Kim et al. 2005; Verdugo and Hoz 2007; Cabalar 2008; Seif

58 El Dine et al. 2010; Ebrahimi 2011; Anbazhagan et al. 2011; Trinh et al. 2012) showed that the

59 mechanical behavior of soil containing a large proportion of fines is strongly influenced by the

60 water content. As the water content changes are governed by the hydraulic behavior of soil, it

61 appears important to assess the influence of fine particles content on the hydraulic behavior of 62 interlayer soil. 
Moreover, in field conditions, the interlayer soil normally undergoes the effect of

64 wetting/drying cycles related to climatic changes. These wetting/drying cycles may induce

65 changes in soil micro-structure, thereby changing the soil hydraulic properties. Therefore, it 66 appears also important to investigate the effect of wetting/drying cycles on the hydraulic 67 conductivity.

To the authors' knowledge, the effects of fines content and wetting/drying cycles on the

69 unsaturated interlayer soil have not been investigated yet. In the present work, laboratory tests

70 were performed using a large-scale infiltration column (300 $\mathrm{mm}$ in diameter) and a small-scale

71 infiltration column (50 $\mathrm{mm}$ in diameter), and the instantaneous profile method was used to

72 determine the hydraulic conductivity of soil. Both wetting and drying paths were performed and

73 different fines contents were considered: natural interlayer soil $\left(I T L_{0}\right)$, natural interlayer soil with

$7410 \%$ of sub-grade added $\left(I T L_{10}\right)$, fine-grained soil prepared by passing $I T L_{10}$ through a $2 \mathrm{~mm}$

75 sieve (Fines). The results enable the assessment of the effects of fine particles and wetting/drying 76 cycles.

\section{Materials studied}

78 The soils (both the interlayer soil and sub-grade) were taken from the railway site Sénissiat

79 (North-West of Lyon, France). Mineralogy analysis reveals that the interlayer soil is a mixture of

80 materials that come from the construction and maintenance (broken stones, gravel, sand, etc) of

81 tracks, the aging process of track components and the sub-grade. It also showed that the fine

82 particles in the interlayer soil mainly come from the sub-grade. The main geotechnical properties

83 of interlayer soil and sub-grade are presented in Table 1. The results show that the sub-grade is

84 high-plasticity silt. More details about the characterization of the interlayer soil can be found in

85 Trinh et al. (2011). 
In order to study the effect of fines contents on the hydraulic behavior of interlayer soil, a

87 quantity of sub-grade representing $10 \%$ of interlayer soil by dry mass was added into the 88 interlayer soil to form a soil with a higher content of fines: $I T L_{10}$. The grain size distribution

89 curves of the natural interlayer soil $\left(I T L_{0}\right)$ and $I T L_{10}$ are presented in Fig. 1.

90 It is worth noting that the migration of fines into ballast is recognized as one of the 91 mechanisms for fouled ballast (Ayres 1986; Selig and Waters 1994; Alobaidi and Hoare 1996;

92 1998; Ghaotara et al. 2006; Mayoraz et al. 2006; Huang et al. 2009; Giannakos 2010; Fortunato

93 et al. 2010; Indraratna et al. 2011; Ebrahimi 2011; Sussmann and Chrismer 2012). Even though

94 the interlayer soil studied here is different from the fouled ballast by nature, in order to compare

95 with the classification of fouled ballast, two parameters for fouled ballast are adopted here: the 96 fouling index $F I$ (Selig and Water 1994) and the relative fouling ratio $R_{b-f}($ Indraratna et al. 2011).

$97 \quad F I$ is defined as:

$$
F I=P_{4}+P_{200}
$$

100 where $P_{4}$ and $P_{200}$ are percentages of ballast passing through sieves $\mathrm{N}^{\circ} 4(4.75 \mathrm{~mm})$ and $\mathrm{N}^{\circ} 200$

$101(0.075 \mathrm{~mm})$, respectively.

103 sieve) to the dry mass of ballast $M_{b}$ (particles retained in $9.5 \mathrm{~mm}$ sieve):

104 [2]

$$
R_{b-f}=\frac{M_{f} \times \frac{G_{s-b}}{G_{s-f}}}{M_{b}} \times 100 \%
$$

105 where $G_{s-f}, G_{s-b}$ are specific densities of fouling particles and ballast, respectively. 
107 the classification, both $I T L_{0}$ and $I T L_{10}$ are "highly fouled". Because $I T L_{10}$ is classified in the

108 highest category of fouling, it was decided to not adding more fine particles to the interlayer soil.

To better evaluate the effect of fines on the hydraulic behavior of interlayer soil, the

110 hydraulic conductivity of pure fine particles was also determined. For this purpose, $I T L_{10}$ was

111 sieved at $2 \mathrm{~mm}$ to obtain the fine part (namely Fines). The grain size distribution curve of Fines

112 is also presented in Fig. 1.

\section{Experimental methods}

114 The interlayer soil was tested in a large-scale infiltration column (Fig. 2). The column (300 mm

115 in diameter and $600 \mathrm{~mm}$ in height) is equipped with five water content sensors (TDR1 to TDR5)

116 and five tensiometers for measuring pore-water pressure (T1 to T5) arranged at various elevations

117 along the column ( $\mathrm{h}=100,200,300,400$ and $500 \mathrm{~mm}$ from the bottom of the soil specimen).

118 The working pressure range of the tensiometers is from $100 \mathrm{kPa}$ to $-85 \mathrm{kPa}$. The accuracy of the

119 TDR used is $\pm 2 \%$ and that of the tensiometer is $\pm 0.5 \mathrm{kPa}$. At each instrumented height, as the

120 area occupied by the sensors is just $6.8 \%$ of the total apparatus section area, the influence of the

121 sensors installation on water transfer is expected to be insignificant.

For the $I T L_{10}$ specimen preparation, water and fine particles were added to the dry natural

123 interlayer soil to reach the target water content and fine particles content, and a large mixer was

124 used to homogenize the material. For the $I T L_{0}$ specimen preparation, only desired quantity of

125 water was added to the dry natural interlayer soil. After mixing, the wet materials were stored in

126 hermetic containers for at least $24 \mathrm{~h}$ for moisture homogenization. Soil compaction was

127 conducted using a vibrating hammer in six layers of $0.10 \mathrm{~m}$ each at a dry unit mass of 2.01 
$128 \mathrm{Mg} / \mathrm{m}^{3}$. The soil for each layer has a same composition as that of the whole sample. Big particles

129 and fine particles were rearranged before the compaction in order to ensure the sample

130 homogenization. Prior to the compaction of the subsequent layer, a TDR probe and a metal rod of

$13125 \mathrm{~mm}$ diameter were placed on the compacted layer.

132 Once the soil specimen was prepared, water was injected from the bottom and it flowed

133 out from the outlet after about half an hour. After saturation of the sample, the metal rods were

134 removed and the tensiometers were installed. This protocol was adopted to avoid damaging the

135 tensiometers during the compaction and also any cavitation due to possible high suction in the

136 column. More details about the large-scale infiltration column can be found in Duong et al.

137 (2013).

138 The TDR is an indirect measurement method and several authors reported that the

139 calibration curve depends on the soil texture, unit mass, mineralogy, fines content and particle

140 size (Jacobsen and Schjønning 1993; Stolte et al. 1994; Côté and Roy 1998; Gong et al. 2003;

141 Schneider and Fratta 2009). It is therefore necessary to determine the specific calibration curve

142 for each soil studied. For the natural interlayer soil $\left(I T L_{0}\right)$, a relationship between volumetric

143 water content $(\theta)$ and the dielectric constant $K_{a}$ was established by Duong et al. (2013). As the

144 soil composition in $I T L_{10}$ is different from $I T L_{0}$, another relationship was needed. This was

145 determined separately with a lower specimen of $200 \mathrm{~mm}$ at the same unit mass in the same

146 column. One TDR sensor was placed in the middle of the sample. Water was added on the

147 surface of the soil specimen to achieve the desired water content. Once the TDR gave a steady

148 response (after about 8 hours), the water content was considered as being uniform within the

149 sample and the value of dielectric constant $K_{a}$ was recorded. This operation was repeated until

150 the specimen reached full saturation (with $1 \mathrm{~cm}$ water on the soil surface). All the TDR sensors 
151 were calibrated in the same fashion. The results obtained on the five sensors are similar. Fig. 3

152 presents the calibration curve of TDR for $I T L_{10}$ along with the fitting calibration curve for $I T L_{0}$

153 presented in Duong et al. (2013) at the same dry unit mass $\left(2.01 \mathrm{Mg} / \mathrm{m}^{3}\right)$. It can be observed that

154 the curve for $I T L_{0}$ lies below the curve for $I T L_{10}$, indicating a clear effect of soil texture. The

155 following equation (based on the model of Topp et al. 1980) was used to fit the experimental data

156 for $I T L_{10}$ :

157

[3] $\theta=-4.16 \times 10^{-5} \times \mathrm{K}_{\mathrm{a}}^{3}+2.11 \times 10^{-3} \times \mathrm{K}_{\mathrm{a}}{ }^{2}-2.36 \times 10^{-2} \times \mathrm{K}_{\mathrm{a}}+0.17$

The infiltration tests were conducted in two wetting/drying cycles. After installation of the

159 tensiometers, the saturation of soil column was completed (Saturation 1). This wetting stage was

160 followed by a draining stage (Drainage 1). Water was allowed to drain out through the bottom

161 valves by keeping a constant water level at the bottom of soil sample using an external water

162 source. The first wetting/drying cycle finished by a stage of evaporation (Evaporation 1) where

163 the top cover of the column was removed to allow soil water evaporation. A fan was used to

164 accelerate the evaporation process. The evaporation stage ended when the suction value indicated

165 by tensiometer $\mathrm{T} 5(\mathrm{~h}=500 \mathrm{~mm})$ was about $60 \mathrm{kPa}$ (higher suction would lead to cavitation). A

166 second wetting-drying cycle was applied following the same procedure (Saturation 2, Drainage 2

167 and Evaporation 2). Before the second drainage, the hydraulic conductivity in saturated state was

168 also measured by applying a constant water head of $0.61 \mathrm{~m}$. The hydraulic gradient was 1 .

169 According to the Tennakoon et al. (2012), hydraulic gradient smaller than 4 can be considered as

170 low enough to ensure the Darcy's law. Note that the experimental procedure with saturation from

171 the bottom and evaporation from the top is also recommended in ASTM standard (ASTM 2010).

172 During the measurement of hydraulic conductivity under saturated condition, the volume of water

173 injected increased linearly with a rate of about $50 \mathrm{~cm}^{3}$ per minute. 
The unsaturated hydraulic conductivity of Fines was determined using a small-scale

175

176

177

178

179

180

181

183

184

185

186

[5]

The dry unit mass and water content of Fines were taken equal to those of fine particles contained in the sample of interlayer soil. Using the illustration shown in Fig. 5, these two parameters can be calculated as follows:

$$
\rho_{d, f}=\frac{M_{s, f}}{V_{f}}=\frac{M_{s}-M_{s, b}}{V-V_{s, b}}=\frac{(1-m) \rho_{d} V}{V-\frac{m}{\rho_{s, b}} \rho_{d} V}=\frac{(1-m) \rho_{d} \rho_{s, b}}{\rho_{s, b}-m \rho_{d}}
$$

$$
w_{f}=\frac{M_{w}}{M_{s, f}}=\frac{M_{s} w}{M_{s}-M_{s, b}}=\frac{w}{1-m}
$$

where $M, M_{w}, M_{s}$ are the total mass, mass of water and mass of solid particles, respectively; $V, V_{w}$,

$188 V_{s}$ are the total volume, volume of water and volume of solid particles respectively; $\rho_{d}, \rho_{s}$ are the

189 dry unit mass of the specimen and unit mass of solid particles, respectively; the subscripts $f$ and $b$

190 stand for particle smaller and larger than $2 \mathrm{~mm}$, respectively; $m$ is the percentage of particles 191 larger than $2 \mathrm{~mm}$.

193 and (3), a value of $1.33 \mathrm{Mg} / \mathrm{m}^{3}$ was obtained for the dry unit mass of Fines. 
The test procedure followed for the small-scale infiltration column was akin to that for the

195 large-scale one. After the suction stabilization, the sample was saturated from the bottom

196 (Saturation 1). After completion of saturation, an external water source was connected to the

197 bottom in order to ensure a constant water level after the drainage. The top cover was then

198 removed allowing water evaporation from the soil surface (Evaporation 1). When suction at 160

$199 \mathrm{~mm}$ reached about $400 \mathrm{kPa}$, Evaporation 1 was stopped to avoid cavitation of the tensiometers. A

200 second wetting-drying cycle was applied by following the same procedure as in the first cycle

201 (Saturation 2 and Evaporation 2).

Unlike the large-scale column where both suction and water content were monitored, the

203 small-scale column has only suction monitored. To obtain the water content changes during 204 infiltration, the soil-water retention curve (SWRC) was needed. The water retention curve (WRC)

205 of compacted Fines was determined separately using the device presented in Fig. 6. The soil was

206 first compacted inside an oedometer cell (the dimensions of the soil specimen are $50 \mathrm{~mm}$ in

207 diameter and $20 \mathrm{~mm}$ in height). The suction of the specimen was monitored by a high-capacity

208 tensiometer fixed at the bottom of the cell. A light aluminum piston of $50 \mathrm{~mm}$ diameter was

209 placed on the specimen to ensure the good contact between soil and tensiometer. The piston

210 induced a vertical stress of $1.8 \mathrm{kPa}$ and its influence was believed to be negligible. For the

211 monitoring of soil water content, the whole system was placed on a balance having an accuracy

212 of $\pm 0.01 \mathrm{~g}$. The mass change indicated the quantity of water added or evaporated. More details

213 about this cell can be found in Le et al. (2011) and Munoz-Castelblanco et al. (2012). Wetting

214 was conducted by adding a small quantity of water on the upper face of the sample, while drying

215 was conducted by allowing soil water evaporation from the upper surface without the piston on it.

216 Once the desired water content was reached, the piston was put on the soil surface and the final

217 suction was recorded. This method was also discussed by Cunningham et al. (2003); Toker et al. 
218 (2004); Loucenço (2008); Loucenço et al. (2011); Toll et al. (2012) and Munoz-Castelblanco et

219 al. (2012).

For the large-scale column, both suction and water content profiles were obtained

221 directly. For the small-scale column, the suction profiles were obtained directly while the water

222 content profiles were determined through the SWRC. The instantaneous profile method (Daniel

223 1982; Delage and Cui 2001; Bruckler et al. 2002; Cui et al. 2008; Ye et al. 2009) was then

224 applied for the determination of hydraulic conductivity for each soil. Note that this method is

225 based on the generalized Darcy's law. The hydraulic gradient is determined by considering the

226 slope of suction isochrones and the water volume passing through a given section between times $t$

227 and $t+d t$ is used for calculating the water flux.

\section{Experimental results}

The results of $I T L_{0}$ were presented in Duong et al. (2013). Here only the results of $I T L_{10}$

230 and Fines are presented in detail, and the results of $I T L_{0}$ are only used for comparison.

Fig. 7 presents changes in pore water pressure and volumetric water content versus time

232 during Drainage 1 and Evaporation 1 for $I T L_{10}$. From the saturated state where the volumetric

233 water content reached $22-25 \%$, water drained out through the bottom valves and subsequently the

234 volumetric water content decreased to $15-17 \%$ at the end of the draining stage for all the TDR

235 sensors except that at $\mathrm{h}=200 \mathrm{~mm}$ (Fig. 7b). At this moment, the pore water pressure was in the

236 range from 0 to $-4 \mathrm{kPa}$ (Fig. 7a). Drainage 1 finished after more than 1 day. During Evaporation

237 1, the pore water pressure given by the tensiometer at $\mathrm{h}=500 \mathrm{~mm}$ decreased quickly while small

238 changes were observed at other levels (Fig. 7a). This is consistent with the values of volumetric 
water content: the value at $\mathrm{h}=500 \mathrm{~m}$ decreased significantly since the beginning of Evaporation

2401 while those at other levels show slight changes (Fig. 7b).

During Saturation 2, the external water source was set at a level applying a water pressure

242 of $6.1 \mathrm{kPa}$ to the bottom of sample. The results obtained show that less than one hour was needed

243 to re-saturate the soil specimen (Fig. 8). The changes were not significant for T1 to T4 (small

244 suction value), while those of $\mathrm{T} 5$ at $\mathrm{h}=500 \mathrm{~mm}$ are quite significant (Fig. 8a). Furthermore, the

245 suction changes in Fig. 8a are consistent with those of volumetric water content in Fig. 8b. At the

246 end of this stage when the pore water pressure became positive at all levels, the 5 tensiometers

247 indicated the values corresponding to the water head at each level $(5.5 \mathrm{kPa}, 4.5 \mathrm{kPa}, 3.5 \mathrm{kPa}, 2.0$

$248 \mathrm{kPa}$ and $1.0 \mathrm{kPa}$ for $\mathrm{T} 1$ to $\mathrm{T} 5$, respectively). The volumetric water content also reached the values

249 of near saturated state (corresponding to the degree of saturations ranging from $87.5 \%$ to $100 \%$ ).

250 The results obtained during Drainage 2 and Evaporation 2 are presented in Fig. 9. During

251 the first two days, water inside the column was connected to the outside water source having a

252 level decreased in steps of $50 \mathrm{~mm}$ from $\mathrm{h}=550$ to $50 \mathrm{~mm}$ in order to verify the response of the

253 sensors. Each step was kept for 1 hour. At the end of Drainage 2, the outside water source was set

254 at $\mathrm{h}=50 \mathrm{~mm}$ and Evaporation 2 started. During the drainage, the volumetric water content

255 decreased quickly while the changes of suction were much slower. As during Evaporation 1, the

256 pore water pressure and the volumetric water content values at $\mathrm{h}=500 \mathrm{~mm}$ decreased

257 significantly while the others remained almost constant. Once again, the changes of suction and

258 volumetric water content are consistent for different levels: the closer to the evaporation surface,

259 the higher the suction (Fig. 9a) and the smaller the volumetric water content (Fig. 9b) (except for

$260 \mathrm{~h}=200 \mathrm{~mm})$. 
262 is related to the deficiency of this sensor. Indeed, some additional calibrations were conducted

263 after the test, and the results showed some inertia of this TDR sensor: in the full range from 0 to

$264100 \%$, no difference with other sensors was observed; however, in a limited range, a clear

265 difference was identified. Thereby, the results by this sensor were not considered in further 266 analysis.

The data of suction and volumetric water content recorded allowed the WRC of the 268 interlayer soil to be determined. The results are presented in Fig. 10 with three paths 269 corresponding to Drainage 1-Evaporation 1 (Drying 1), Saturation 2 (Wetting 2) and Drainage 1-

270 Evaporation 2 (Drying 2). It can be observed that the results of two drying processes are close. In 271 contrast, the result of wetting path lies above. Note that because the minimum recording interval 272 of TDR was every minute and the wetting process took place very quickly; there are less data for 273 the wetting path. The model of van Genuchten (1980) was used to fit the experimental data with 274 the parameters presented in Table 3.

The hydraulic conductivity versus suction is presented in Fig. 11, including the hydraulic

276 conductivity measured at saturated state, equal to $1.67 \times 10^{-5} \mathrm{~m} / \mathrm{s}$. It can be seen that the results for

277 the two drying paths are similar, suggesting negligible microstructure changes. For the wetting 278 path, all results lie above those of the drying paths, illustrating a clear phenomenon of hysteresis.

279 The models of van Genuchten (1980) and Brooks-Corey (Brooks and Corey 1964; Stankovich 280 and Lockington 1995) were used for fitting the data of both drying and wetting paths using the 281 least squares method (see Fig. 11). The parameters determined are presented in Table 4 .

Fig. 12 presents the comparison between the WRC of $I T L_{0}$ and $I T L_{10}$ for the drying path 283 (the parameters of van Genuchten's model (1980) used for fitting the experimental data are 
presented in Table 3). Note that for clarity, the scattered data at low suction are not included. The 285 WRC of $I T L_{0}$ is beneath the WRC of $I T L_{10}$, suggesting that at a given suction, $I T L_{10}$ has a higher 286 water content than $I T L_{0}$. This appears normal because with the same dry unit mass, the higher the 287 fines content, the higher the retention capacity.

The comparison of hydraulic conductivity between $I T L_{0}$ and $I T L_{10}$ is presented in Fig. 13.

289 In the saturated state, the two soils have almost the same value: $1.67 \times 10^{-5} \mathrm{~m} / \mathrm{s}$ for $I T L_{10}$ and

$2901.75 \times 10^{-5} \mathrm{~m} / \mathrm{s}$ for $I T L_{0}$. Both values are lower than the critical value proposed by Selig and 291 Waters (1994) for the railway substructures. In unsaturated state, even the data are scattered for 292 the two soils, an identical trend can be identified: the hydraulic conductivity is decreasing with 293 the increase of suction. Moreover, the average value for $I T L_{10}$ is slightly higher than that for $I T L_{0}$, 294 suggesting a slightly greater hydraulic conductivity for $I T L_{10}$. On the whole, the difference 295 between the hydraulic conductivity results of two soils is less evident than the difference between 296 the SWRC results.

The results obtained from the small-scale infiltration test on Fines are shown in Fig. 14 to

298 Fig. 18. After installation of the tensiometers, a period of 18 hours was needed to reach the 299 suction equilibrium at $70-83 \mathrm{kPa}$ (Fig. 14). This difference in final suctions at different levels 300 was mainly related to the soil heterogeneity. The corresponding degree of saturation was $43 \%$.

301 From this initial state, the soil was first re-saturated by injecting water from the bottom with a 302 constant water head of $0.7 \mathrm{kPa}$. The suction at the lowest level changed first, followed by the 303 suctions at higher levels (Fig. 15). Ten minutes after the water injection, water appeared on the 304 upper surface and suctions at all level reached zero, indicating the full saturation of the soil 305 specimen. 
After Saturation 1, water was drained out to an outside water source and the water level

307 was maintained at $\mathrm{h}=0$. Afterwards, Evaporation 1 took place. The results obtained are shown in

308 Fig. 16. Fifteen hours later, the pore water pressure measured at $\mathrm{h}=160 \mathrm{~mm}(40 \mathrm{~mm}$ below the

309 soil surface) started to decrease and reached $-300 \mathrm{kPa}$ at 57 hours. The changes in water pressures

310 measured by other tensiometers were less significant.

311 Saturation 2 took place right after Evaporation 1. The results obtained during this second

312 wetting stage are shown in Fig. 17. Less than 2 minutes was required for the pore water pressure

313 at $\mathrm{h}=160 \mathrm{~mm}$ to come back from $-300 \mathrm{kPa}$ to about 0 . The results obtained during the

314 subsequent drying are shown in Fig. 18 (Evaporation 2). As in the case of Evaporation 1, after 80

315 hours, the pore water pressure at $\mathrm{h}=160 \mathrm{~mm}$ decreased to $-365 \mathrm{kPa}$ while those at other levels

316 did not change significantly.

317 The results from the test in the tensiometer-equipped oedometer are shown in Fig. 19. Fig.

318 19a depicts the suction (negative pore water pressure given by the tesiometer) evolution after the

319 tensiometer installation. The suction increased and reached its stabilization value of $110 \mathrm{kPa}$ after

32017 hours. This corresponds to the initial state of the soil specimen (21.3\% volumetric water

321 content and $42.6 \%$ degree of saturation). Water was then added into the specimen to follow the

322 wetting path. The variation of the first step of wetting is presented in Fig. 19b. About 35 minutes

323 was needed for suction stabilization. The volumetric water content in this step increased from

$32421.3 \%$ to $21.7 \%$. This operation was repeated until the soil reached the near saturated state. Then

325 the drying steps started. Fig. 19c presents the suction stabilization during one drying step. An

326 equilibrium value of $79 \mathrm{kPa}$ was reached after 320 minutes. This suction increase corresponded to

327 a decrease of volumetric water content from $22.2 \%$ to $21.6 \%$. 
The SWRC obtained for Fines is shown in Fig. 20. From its initial state, the soil specimen was subjected to wetting up to $70 \%$ degree of saturation, followed by drying and finally a second

330 wetting till full saturation. It can be seen that the SWRC obtained during drying lies above that

331 during wetting. The maximum suction value was $390 \mathrm{kPa}$ corresponding to a volumetric water 332 content of $18.9 \%$; it was also close to the maximum suction value in the specimen during the 333 infiltration test, indicating the compatibility of the two tests.

This SWRC determined was then used to calculate the changes of volumetric water

335 content in the small-scale infiltration column based on the suction changes presented in Fig. 15 to

336 Fig. 18. Either the drying or the wetting path was used depending on the path followed in the

337 infiltration test. As the second drying path of SWRC was not available, the first drying path was

338 used for calculating the volumetric water content during the second drying path in the infiltration

339 test. Then, based on the profiles of suction and water content, the hydraulic conductivity of

340 compacted Fines was calculated. The results are shown in Fig. 21, including the hydraulic

341 conductivity measured at saturated state by applying a constant water pressure of $0.7 \mathrm{kPa}$ :

$3422.6 \times 10^{-6} \mathrm{~m} / \mathrm{s}$. Albeit the large data scatter, a clear trend can be observed: as for the interlayer soil,

343 the hydraulic conductivity increased when the suction decreased.

344 It is worth noting that the results obtained for the two drying paths are quite similar. The 345 same conclusion can be drawn for the two wetting paths. The models of van Genuchten (1980)

346 and Brooks-Corey (Brooks and Corey 1964; Stankovich and Lockington 1995) were used to fit 347 the results (Fig. 21), and the parameters determined are presented in Table 4. Comparison 348 between the drying and wetting curves shows that for the 2 wetting/drying cycles, the wetting 349 curves lie always above the drying curves. It is opposed to the SWRC where the wetting curves 350 are normally beneath the drying ones. In addition, the curves of wetting path and drying path of 
351 the $1^{\text {st }}$ cycle are close to those corresponding to the $2^{\text {nd }}$ cycle, suggesting no effect of

352 wetting/drying cycles on the hydraulic conductivity. The smallest value of hydraulic conductivity

353 identified is $6 \times 10^{-12} \mathrm{~m} / \mathrm{s}$ corresponding to a suction value of $242 \mathrm{kPa}$, while the highest one is

$3542.6 \times 10^{-6} \mathrm{~m} / \mathrm{s}$ corresponding to the saturated state.

Fig. 22 depicts the comparison of SWRC between $I T L_{10}$ and Fines in the plane of degree 356 of saturation versus suction. The two curves start from almost the same point - around 97\%

357 degree of saturation and $1.7 \mathrm{kPa}$ suction. From $3 \mathrm{kPa}$ suction, the WRC of $I T L_{10}$ starts to separate

358 from the WRC of $I T L_{0}$. The two curves are parallel (for drying path) from $10 \mathrm{kPa}$ suction. The

359 curves of $I T L_{10}$ stop at $71 \mathrm{kPa}$ while the curves of Fines stop at $389 \mathrm{kPa}$ due to the different

360 capacities of the tensiometers used for the two soils. The gap between two curves is about $10 \%$ of

361 degree of saturation at the end of the curve for $I T L_{10}$.

In Fig. 23, the hydraulic conductivity of $I T L_{10}$ and Fines is plotted versus suction. It can

363 be observed that the wetting and drying curves of the interlayer soil are quite close to those of

364 Fines, suggesting that the hydraulic conductivity of the interlayer soil is mainly governed by the

365 hydraulic conductivity of the fines contained in it. In other words, water transfer in the interlayer

366 soil takes place mainly through the network of pores between fine particles, coarse elements like

367 ballast behaving as inert materials. This is confirmed by the hydraulic conductivity values at

368 saturated state: similar values were identified $-1.67 \times 10^{-5} \mathrm{~m} / \mathrm{s}$ for $I T L_{10}$ against $2.6 \times 10^{-6} \mathrm{~m} / \mathrm{s}$ for

369 Fines.

From a practical point of view, Fig. 23 shows that to determine the hydraulic conductivity

371 of interlayer soils, it is not necessary to use large-scale experimental devices to match the soil

372 grain size; smaller devices can be used to determine their hydraulic conductivity by testing the

373 fine particles only, provided that equivalent dry density is accounted for. 


\section{Discussions}

375 Fig. 11 and Fig. 21 show the uncommon phenomenon of hystersis observed in hydraulic

376 conductivity of $I T L_{10}$ and Fines, respectively. The curve of wetting path lies above the curve of

377 drying path. The same phenomenon was observed by Wayllace and Lu (2011). The following

378 interpretations can be attempted.

379 Due to the different kinetic between the fast liquid transfer in wetting and the long vapor

380 transfer in drying, the time needed for drying was much longer than that for wetting. This

381 phenomenon was also reported by Toker et al. (2004) and discussed by Munoz-Castelblanco et

382 al. (2012). A higher hydraulic conductivity can be expected in that case for wetting path.

In the present work, the calculation of hydraulic conductivity was performed based on the suction evolution given by tensiometers. Assuming that in the compacted soils, both macro-pores and micro-pores existed. During wetting, the macro-pores were filled with water more quickly than micro-pores. Moreover, in the micro-pores, there were always air bubbles preventing the total saturation. In contrast, during drying, all pores (micro and macro) participated in the evaporation process. As a result, when water filled the macro-pores, the tensiometers immediately gave the suction changes corresponding to the water flow through the macro-pores,

390 even though the suction in micro-pores would be higher. On the contrary, when water evaporates

391 during drying, the tensiometers gave the suction changes that involve both macro and micro-

392 pores, in a much slower fashion. In other words, the suction measured by the tensiometers was

393 probably under-estimated for wetting paths. Côté and Roy (1998) also reported that one re-

394 saturating stage is not enough to fully saturate a soil sample because of the air bubbles trapped in

395 micro-pores. This can also explain the uncommon hysteresis mentioned before. 
Poulovassilis (1969) (cited by Mualem 1976) considered, in a qualitative way, the

397 influence of capillary hysteresis on the hydraulic conductivity based on the concept of 398 independent domain theory. He defined two mechanisms related to hysteresis: (i) water fills pores

399 of larger opening radius in a wetting process than in drying one; (ii) the pores configuration and 400 interconnection may be different for wetting and drying. As a result, the hydraulic conductivity in

401 wetting may be different from that in drying for the same water content. The theory about the

402 difference between the opening radius affecting wetting process and the opening radius affecting 403 drying process is known as the effect of ink-bottle (Bertotti and Mayergoyz 2006; Naumov 404 2009). According to this theory, the pores affecting the wetting curve are larger than the pores 405 affecting the drying curve. As a result, the water transfer is faster during wetting than during 406 drying, implying a higher hydraulic conductivity in the case of wetting.

\section{Conclusions}

408 Infiltration tests were performed on the interlayer soil $\left(I T L_{0}\right)$ and its derived soils - adding $10 \%$ of 409 sub-grade to form $I T L_{10}$ and sieving $I T L_{10}$ at $2 \mathrm{~mm}$ to form Fines. Two wetting/drying cycles 410 were applied for each test. The obtained results allowed the effect of fine particles on the water 411 retention capacity and hydraulic conductivity of interlayer soil to be analyzed.

412 The effect of wetting/drying cycles on hydraulic conductivity was found negligible - the 413 results of the first cycle are quite similar to those of the second cycle, suggesting an insignificant 414 microstructure change by wetting/drying cycles.

416 changes with suction. The wetting process was found to be much faster than the drying process, 417 and the hydraulic conductivity during wetting is always higher than that during drying. This can 
418 be explained by the effect of ink-bottle and the difference between the water transfer through the

419 network of macro-pores and micro-pores.

Adding $10 \%$ fine particles to the natural interlayer soil changes the soil water retention

421 curve but does not induce significant changes in hydraulic conductivity. In saturated state, the

422 hydraulic conductivity of natural interlayer soil is $1.75 \times 10^{-5} \mathrm{~m} / \mathrm{s}$, while the value of the soil with

$42310 \%$ fines added is $1.67 \times 10^{-6} \mathrm{~m} / \mathrm{s}$. In unsaturated state, even though the results are little scattered,

424 the results of $I T L_{10}$ are within the variation range of the results of $I T L_{0}$. However, it is worth

425 noting that the mean value of $I T L_{10}$ is slightly greater than that of $I T L_{0}$.

426 The water retention curves of $I T L_{10}$ and Fines are different, illustrating an obvious effect

427 of soil texture. On the contrary, in terms of hydraulic conductivity including the values in

428 saturated state, a good agreement was identified between the results of two soils, regardless of the

429 drying or wetting paths. This suggests that water transfer in the interlayer soil takes place mainly

430 through the network of pores between fine particles, coarse elements like ballast behaving as inert

431 materials. From a practical point of view, this finding shows that to determine the hydraulic

432 conductivity of interlayer soils, a device as small as the small-scale infiltration cell can be

433 employed to determine the hydraulic conductivity of interlayer soil by testing the fine particles

434 only, provided that equivalent dry density is taken into account.

436 Acknowledgements

437 The present work is part of the project RUFEX (Re-use of ancient railway platforms and existing 438 foundations) funded by the French National Research Agency. The supports of French Railway 439 Company (SNCF) and Ecole des Ponts ParisTech are also gratefully acknowledged. 
441

442

443

444

445

446

447

448

449

450

451

452

453

454

455

456

457

458

459

460

461

462

463

464

465

466

467

468

469

470

471

Alobaidi, I., and Hoare, D. 1996. The development of pore water pressure at the sub-gradesubbase interface of a highway pavement and its effect on pumping of fines. Geotextiles and geomembranes, 14: 111-135.

Alobaidi, I., and Hoare, D. 1998. The role of geotextile reinforcement in the control of pumping at the sub-grade-subbase interface of highway pavements. Geosynthetics International, 5(6): 619636.

AFNOR. 2005. Identification and classification of soil- Part 2: Principles for a classification. NF EN ISO 14688.

Anbazhagan, P., Lijun, S., Buddhima, I., and Cholachat, R. 2011. Model track studies on fouled ballast using ground penetrating radar and multichannel analysis of surface wave. Journal of Applied Geophysics, 74(4): 175-184.

ASTM 2010. Standard test method for measurement of hydraulic conductivity of unsaturated soils. D7664-10.

Ayres, D. 1986. Geotextiles or geomembranes in track? British railways' experience. Geotextiles and Geomembranes, 3(2-3): 129-142.

Babic, B., Prager, A., and Rukavina, T. 2000. Effect of fine particles on some characteristics of granular base courses. Materials and Structures, 7(33): 419-424.

Bertotti, G., and Mayergoyz, I. D. 2006. The science of hysteresis III. Academic Press

Brooks, R.H., and Corey, A.T., 1964. Hydraulic properties of porous media. Hydro. Paper No.3, Colorado State Univ., Fort Collins, Colo.

Bruckler, L. B., Angulo-Jaramillo, P., and Ruy, R. 2002. Testing an infiltration method for estimating soil hydraulic properties in the laboratory. Soil Science Society of America Journal, 66: $384-395$.

Cabalar, A. 2008. Effect of fines content on the behavior of mixed specimens of a sand. Electronic Journal of Geotechnical Engineering, 13(D): 1-11.

Côté, J., and Roy, M. 1998. Conductivité hydraulique de matériaux de fondations de chaussées partiellement saturés (In French). Rapport de l'études et recherches en transports du Québec, $177 \mathrm{p}$.

Cui, Y.J., Duong, T.V., Tang, A.M., Dupla, J.C., Calon, N., and Robinet, A. 2013. Investigation of the hydro-mechanical behaviour of fouled ballast. Journal of Zhejiang University-Science A (Applied Physics \& Engineering), 14(4): 244-255. 
472 Cui, Y. J., Tang, A. M., Mantho, A., and Delaure, E. 2008. Monitoring field soil suction using a 473 miniature tensiometer. Geotechnical Testing Journal, 31(1) : 95-100.

474 Cui, Y. J., Tang, A. M., Loiseau, C., and Delage, P. 2008. Determining the unsaturated hydraulic 475 conductivity of a compacted sand-bentonite mixture under constant-volume and free-swell 476 conditions. Physics and Chemistry of the Earth, Parts A/B/C, 33: S462-S471.

477 Cunningham, M., Ridley, A., Dineen, K., and Burland, J. 2003. The mechanical behaviour of a 478 reconstituted unsaturated silty clay. Géotechnique, 53 (2): 183-194.

479 Daniel, D. E. 1982. Measurement of hydraulic conductivity of unsaturated soils with 480 thermocouple psychometers. Soil Science Society of American Journal, 46(6): 1125-1129.

481 Delage, P., and Cui, Y. J. 2001. Comportement mécanique des sols non saturés. Article C302. Ed. 482 Techniques Ingénieur.

483 Duong, T. V., Tang, A. M., Cui., Y. J., Trinh, V. N., and Calon, N. 2013. Development of a 484 large-scale infiltration column for studying the hydraulic conductivity of unsaturated fouled 485 ballast. Geotechnical Testing Journal, 36(1): 55-63.

486 Ebrahimi, A. 2011. Behavior or fouled ballast. Railway Track and Structures, 107(8): 25-31.

487 Fortunato, E., Pinelo, A., and Matos Fernandes, M. 2010. Characterization of the fouled ballast 488 layer in the substructure of a 19th century railway track under renewal. Soils and Foundations, 489 50(1): 55-62.

490 Ghataora, G., Burns, B., Burrow, M., and Evdorides, H. 2006. Development of an index test for 491 assessing anti-pumping materials in railway track foundations. Proc.,First International 492 Conference on Railway Foundaitons. 355-366.

493 Giannakos, K. 2010. Loads on track, ballast fouling, and life cycle under dynamic loading in 494 railways. Journal of Transportation Engineering, 136(12): 1075-1084.

495 Gong, Y., Cao, Q., and Sun, Z. 2003. The effects of soil bulk density, clay content and 496 temperature on soil water content measurement using time-domain reflectometry. Hydrological 497 Processes, 17(18): 3601-3614.

498 Huang, H., Tutumluer, E., and Dombrow, W. 2009. Laboratory characterization of fouled 499 railroad ballast behavior. Transportation Research Record: Journal of the Transportation 500 Research Board, 2117(1): 93-101.

501 Indraratna, B., Salim, W., and Rujikiatkamjorn, C. 2011. Advanced Rail Geotechnology 502 Ballasted Track. CRC Press.

503 Jacobsen, O. H., and Schjønning, P. 1993. A laboratory calibration of time domain reflectometry 504 for soil water measurement including effects of bulk density and texture. Journal of Hydrology, 505 151(2-4): 147-157. 
Kim, D., Sagong, M., and Lee, Y. 2005. Effects of fine aggregate content on the mechanical properties of the compacted decomposed granitic soils. Construction and Building Materials, 508 19(3): 189-196.

509 Le, T.T., Cui, Y.J., Muñoz, J.J., Delage, P., Tang, A.M., and Li; X.L. 2011. Studying the stress510 suction coupling in soils using an oedometer equipped with a high capacity tensiometer. Frontiers 511 of Architecture and Civil Engineering in China 5(2): 160-170.

512 Lourenço, S. 2008. Suction measurements and water retention in unsaturated soils. 513 PhD dissertation, Durham University.

514 Lourenço, S., Gallipoli, D., Toll, D., Augarde, C., and Evans, F. 2011. A new procedure for the 515 determination of soil-water retention curves by continuous drying using high-suction 516 tensiometers. Canadian Geotechnical Journal, 48(2): 327-335

517 Mayoraz, F., Vulliet, L., and Laloui, L. 2006. Attrition and particle breakage under monotonic 518 and cyclic loading. Comptes Rendus Mécanique, 334(1): 1-7.

519 Mualem, Y. 1976. Hysteretical models for prediction of the hydraulic conductivity of unsaturated 520 porous media. Water Resources Research, 12(6): 1248-1254.

521 Munoz, J. J., De Gennaro, V., and Delaure, E. 2008. Experimental determination of unsaturated hydraulic conductivity in compacted silt. In Unsaturated soils: advances in geo-engineering: proceedings of the 1st European Conference on Unsaturated Soils, E-UNSAT 2008, Durham, 524 United Kingdom, 2-4 July 2008, pp.123-127.

525 Munoz-Castelblanco, J. A., Pereira, J. M., Delage, P., and Cui, Y. J. 2012. The water retention 526 properties of a natural unsaturated loess from northern France. Géotechnique, 62(2): 95-106.

527 Naumov, S. 2009. Hysteresis phenomenon in Mesoporous Materials. PhD Dissertation, 528 University of Leipzig.

529 Naeini, S., and Baziar, M. 2004. Effect of fines content on steady-state strength of mixed and 530 layered specimens of a sand. Soil Dynamics and Earthquake Engineering, 24(3): 181-187.

531 Pedro, L. 2004. De l'étude du comportement mécanique de sols hétérogènes modèles à son 532 application au cas des sols naturels. PhD disertation, Ecole Nationale des Ponts et Chaussées, 533 France. (In French).

534 Poulovassilis, A. 1969. The effect of hysteresis of pore water on the hydraulic conductivity. Soil 535 Science, 20: 52-56.

536 Schneider, J. M., and Fratta, D. 2009. Time-domain reflectometry - parametric study for the 537 evaluation of physical properties in soils. Canadian Geotechnical Journal, 46(7): 753-767.

538 Selig, E. T., and Waters, J. M. 1994. Track geotechnology and substructure management. 539 Thomas Telford. 
Seif El Dine, S., Dupla, J., Frank, R., Canou, J., and Kazan, Y. 2010. Mechanical characterization of matrix coarse-grained soils with a large-sized triaxial device. Canadian Geotechnical Journal, 542 47(4): 425-438.

543 Stankovich J. M., and Lockington, D. A., 1995. Brooks-Corey and van Genuchten, soil-water544 retention models. Journal of Irrigation and Drainage Engineering, 121(1): 1-7.

545 Stolte, J., Veerman, M ., Wosten, G. J., Freijer, J. H. M., Bouten, J. I ., Dirksen, W., Van Dam, 546 C., and Van den Berg, J.C. 1994. Comparison of six methods to determine unsaturated soil hydraulic conductivity. Soil Science Society of America Journal, 58(6): 1596-1603.

548 Sussmann, T. R., Ruel, M., and Christmer, S. 2012. Sources, influence, and criteria for ballast 549 fouling condition assessment. Proc., 91st Annual Meeting of the Transportation Research Board. $55011 \mathrm{p}$.

551 Tennakoon, N., Indraratna, B., Rujikiatkamjorn, C., Nimbalkar, S., and Neville, T. 2012. The role 552 of ballast-fouling characteristics on the drainage capacity of a rail substructure. Geotechnical 553 Testing Journal, 35(4): 1-12.

554 Toker, N., Germaine, J., Sjoblomt, K. and Culligan, P. 2004. A new technique for rapid 555 measurement of continuous soil moisture characteristic curves. Géotechnique, 54(3): 179-186.

556 Toll, D., Lourenço, S., and Mendes, J. 2012. Advances in suction measurements using high suction tensiometers. Engineering Geology. doi.org/10.1016/j.enggeo.2012.04.013.

558 Topp, G. C., Davis, J. L., and Annan, A. P. 1980. Electromagnetic determination of soil water 559 content: measurements in coaxial transmission lines. Water Resource Research, (16): 574-582.

560 Trinh, V.N. 2011. Comportement hydromécanique des matériaux constitutifs de plateformes 561 ferroviaires anciennes. (In French). PhD Dissertation, Ecole Nationales des Ponts et Chaussées 562 Université Paris - Est.

563 Trinh, V. N., Tang, A. M., Cui, Y. J., Canou, J., Dupla, J.C., Calon, N., Lambert, L., Robinet, 564 A., and Schoen, O. 2011. Caractérisation des matériaux constitutifs de plate-forme ferroviaire 565 ancienne. (In French). Revue Française de Géotechnique, (134-135): 65-74.

566 Trinh, V.N., Tang, A.M., Cui, Y.J., Dupla, J.C., Canou, J., Calon, N., Lambert, L., Robinet, A., 567 and Schoen, O. 2012. Mechanical characterisation of the fouled ballast in ancient railway track 568 substructure by large-scale triaxial tests. Soils and Foundations, 52(3): 511-523.

569 van Genuchten, M.T. 1980. A closed-form equation for predicting the hydraulic conductivity of 570 unsaturated soils. Soil Science Society of America Journal, 44(5): 892-898.

571 Verdugo, R., and Hoz, K. 2007. Strength and stiffness of coarse granular soils. Solid Mechanics 572 and Its Application, 146(3): 243-252. 
573 Wayllace, A., and Lu, N. 2011. A transient water release and imbibitions method for rapidly 574 measuring wetting and drying soil water retention and hydraulic conductivity functions. 575 Geotechnical Testing Journal, 35(1): 1-15.

576 Ye, W. M., Cui, Y. J., Qian, L. X., and Chen, B. 2009. An experimental study of the water 577 transfer through compacted GMZ bentonite. Engineering Geology, 108(3): 169- 176.

578 
580 Table 1: Properties of the soil studied

581 Table 2: Fouling state of the interlayer soil

582 Table 3: Parameters of the van Genuchten's model (1980) for the soil water retention curves of 583 interlayer soil

584 Table 4: Parameters of the van Genuchten's model and Brooks-Corey's model for the hydraulic 585 conductivity of $I T L_{10}$ and Fines

\section{List of figures}

Fig. 1: Grain size distribution curves of the interlayer soil $\left(I T L_{0}\right)$ and its derived ones $\left(I T L_{10}\right.$ and

589 Fines)

590 Fig. 2: Schematic view of the large-scale infiltration column

591 Fig. 3: Calibration curves of the TDRs used for the $I T L_{10}$ and $I T L_{0}$ specimens

592 Fig. 4: Schematic view of the small-scale infiltration column

593 Fig. 5: Components of the unsaturated interlayer soil

594 Fig. 6: Device for determining the WRC of Fines

595 Fig. 7: Test on $I T L_{10}$ : pore water pressure and volumetric water content evolutions during

596 Drainage 1 and Evaporation 1

597 Fig. 8: Test on $I T L_{10}$ : pore water pressure and volumetric water content evolutions in Saturation 2

598 Fig. 9: Test on $I T L_{10}$ : pore water pressure and volumetric water content evolutions during

599 Drainage 2 and Evaporation 2

600 Fig. 10: WRC of $I T L_{10}$ with fitting curves using the van Genuchten's model (1980)

601 Fig. 11: Hydraulic conductivity of $I T L_{10}$ obtained with drying-wetting cycles

602 Fig. 12: Comparison of SWRC between $I T L_{0}$ and $I T L_{10}$

603 Fig. 13: Comparison of hydraulic conductivity between $I T L_{0}$ and $I T L_{10}$

604 Fig. 14: Test on Fines: suction stabilization after the installation of tensiometers

605 Fig. 15: Test on Fines: suction evolutions during Saturation 1

606 Fig. 16: Test on Fines: suction evolutions during Evaporation 1

607 Fig. 17: Test on Fines: suction evolutions during Saturation 2

608 Fig. 18: Test on Fines: suction evolutions during Evaporation 2

609 Fig. 19: Stabilization of suction during the SWRC determination. (a) initial stabilization after

610 tensiometer installation, (b) a wetting stage, (c) a drying stage

611 Fig. 20: WRC of Fines

612 Fig. 21: Hydraulic conductivity of Fines, obtained with drying/wetting cycles

613 Fig. 22: Comparison of SWRC between $I T L_{10}$ and Fines

614 Fig. 23: Comparison of hydraulic conductivity between $I T L_{10}$ and Fines 
Table 1: Properties of the soil studied

\begin{tabular}{|c|c|c|}
\hline Soil & Properties & Value \\
\hline \multirow[t]{7}{*}{ Interlayer soil $\left(I T L_{0}\right)$} & $\rho_{s}($ particles smaller than $2 \mathrm{~mm})$ & $2.67 \mathrm{Mg} / \mathrm{m}^{3}$ \\
\hline & $\rho_{s}($ particles larger than $2 \mathrm{~mm})$ & $2.68 \mathrm{Mg} / \mathrm{m}^{3}$ \\
\hline & $d_{10}$ & $0.01 \mathrm{~mm}$ \\
\hline & $d_{30}$ & $5 \mathrm{~mm}$ \\
\hline & $d_{60}$ & $30 \mathrm{~mm}$ \\
\hline & liquid limit $w_{L}$ (smaller than $\left.100 \mu \mathrm{m}\right)$ & $40.2 \%$ \\
\hline & plasticity index $I_{p}($ smaller than $100 \mu \mathrm{m})$ & $11.3 \%$ \\
\hline \multirow{2}{*}{$\begin{array}{l}\text { Sub-grade (Fines to } \\
\left.\text { create } I T L_{10}\right)\end{array}$} & liquid limit $w_{L}$ & $57.8 \%$ \\
\hline & plasticity index $I_{p}$ & $24.1 \%$ \\
\hline
\end{tabular}

619 Table 2: Fouling state of the interlayer soil

\begin{tabular}{|l|c|c|c|}
\hline & Fouling Index & Relative ballast fouling ratio & Fouling category \\
& $F I(-)$ & $R_{b-f}(\%)$ & \\
\hline$I T L_{0}$ & 45 & 56 & Highly fouled \\
\hline$I T L_{10}$ & 59 & 72 & Highly fouled \\
\hline
\end{tabular}

620 
Table 3: Parameters of the van Genuchten's model (1980) for the soil water retention curves of interlayer soil

\begin{tabular}{|l|l|l|l|l|}
\hline \multicolumn{1}{|l|}{} & $\begin{array}{l}\text { Natural interlayer soil } \\
\left(I T L_{0}\right)\end{array}$ & \multicolumn{2}{|l|}{ Interlayer soil with 10\% sub-soil added $\left(I^{\prime T L} L_{10}\right)$} \\
\hline Formula & Drying & Drying 1 & Wetting 2 & Drying 2 \\
\hline$\theta_{r}+\frac{\theta_{s}-\theta_{r}}{\left[1+(\alpha h)^{n}\right]^{m}}$ & $\theta_{s}=25$ & $\theta_{s}=25$ & $\theta_{s}=22.5$ & $\theta_{s}=25$ \\
& $\theta_{r}=0$ & $\theta_{r}=10$ & $\theta_{r}=10$ & $\theta_{r}=10$ \\
& $\alpha=4$ & $\alpha=159.62$ & $\alpha=0.19$ & $\alpha=113.45$ \\
& $n=1.17$ & $n=1.24$ & $n=5.24$ & $n=1.25$ \\
& $m=0.15$ & $m=0.19$ & $m=0.81$ & $m=0.2$ \\
\hline
\end{tabular}

622 Notes: $\theta$ is volumetric water content $(\%) ; \theta_{s}$ is the volumetric water content at saturated state $(\%)$;

$623 \theta_{r}$ is the residual volumetric water content $(\%) ; h$ is hydraulic head in meter; $\alpha, n, m$ are the 624 model's parameters

625 Table 4: Parameters of the van Genuchten's model and Brooks-Corey's model for the hydraulic conductivity 626 of $I T L_{10}$ and Fines

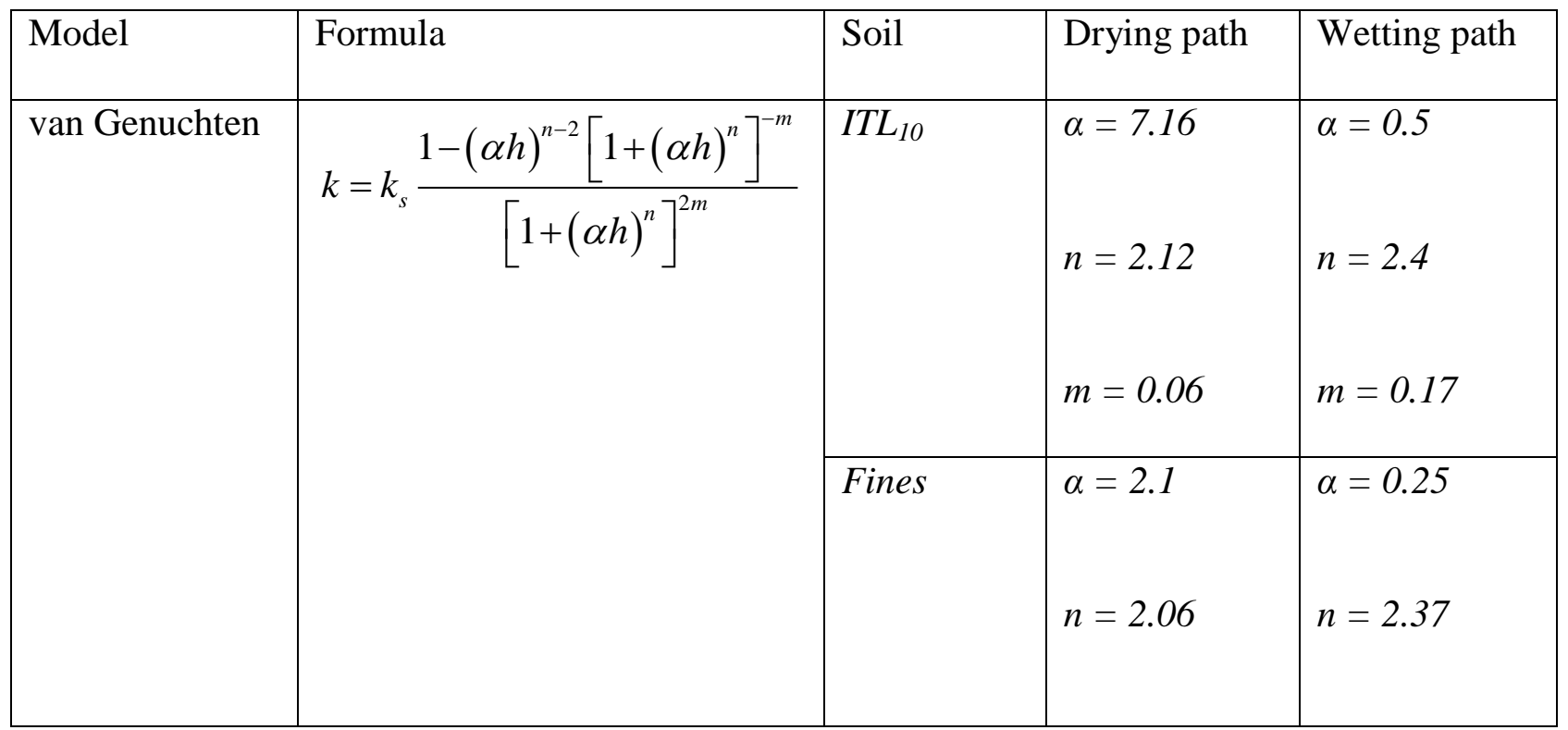




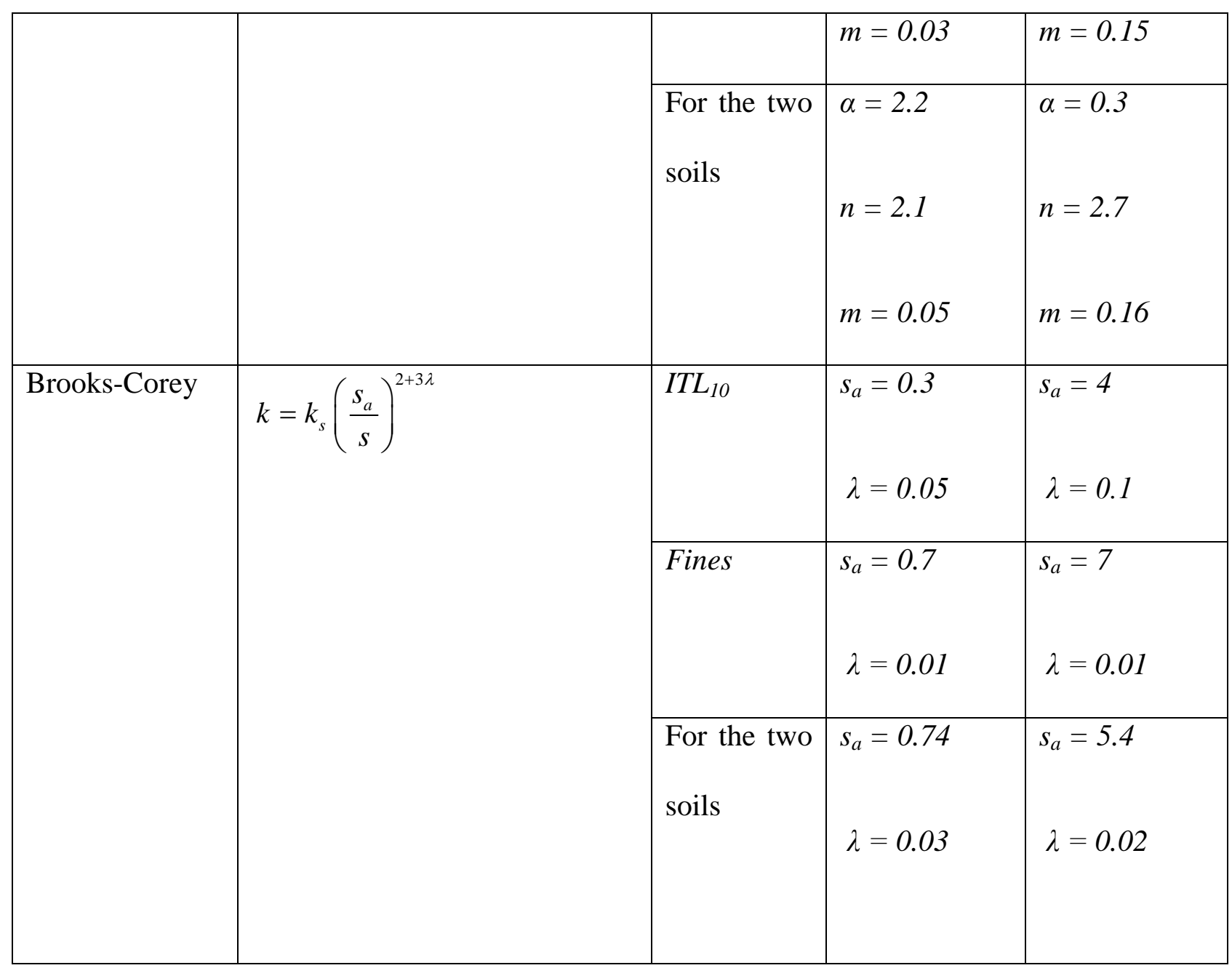

627 Notes: $k$ is the hydraulic conductivity; $k_{s}$ is the hydraulic conductivity in saturated state; $h$ is 628 hydraulic head in meter; $s$ is the suction $(\mathrm{kPa}) ; s_{a}$ is the air-entry value $(\mathrm{kPa}) ; \lambda, \alpha, n, m$ are 629 parameters of the models. 


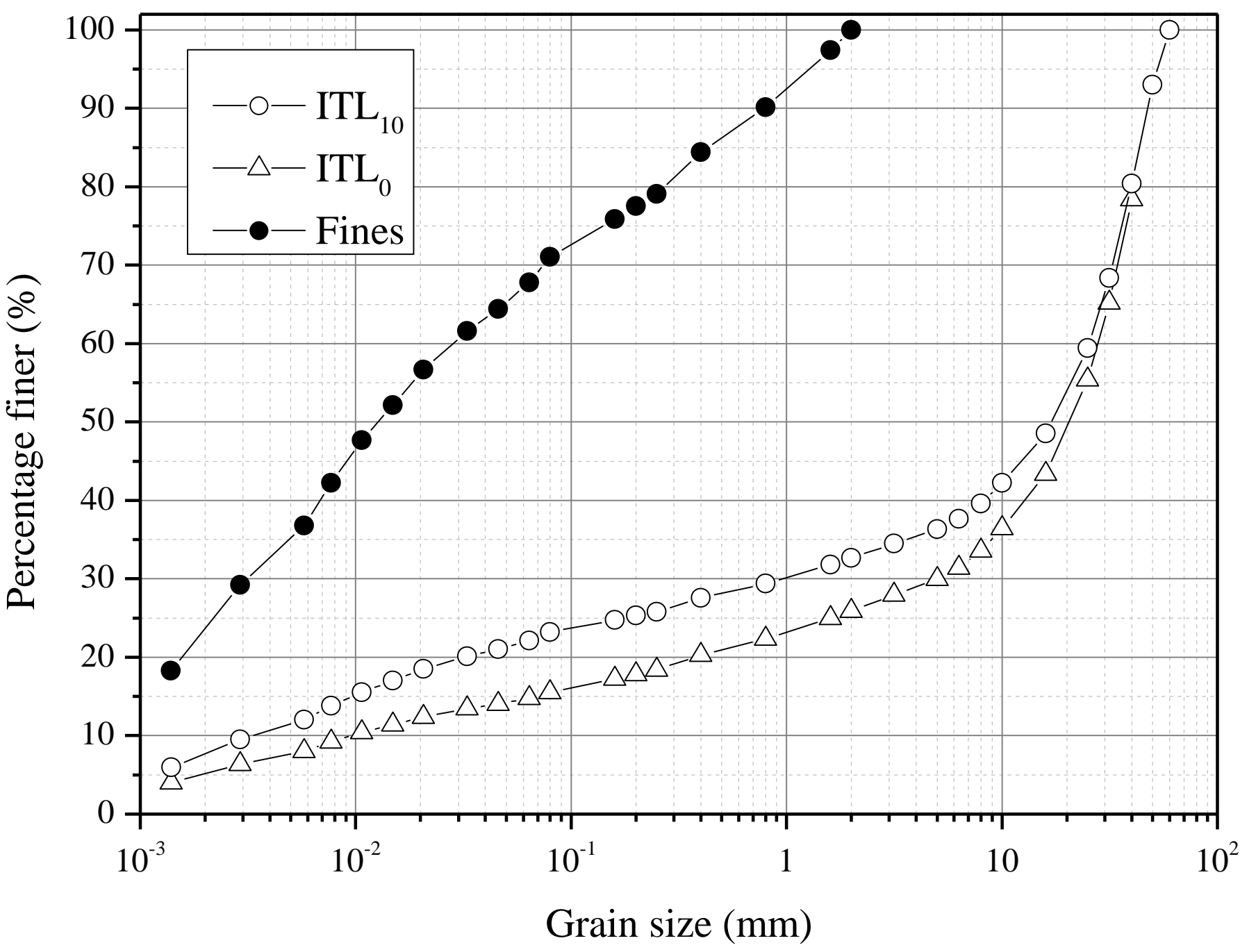

630

631

Fig. 1: Grain size distribution curves of the interlayer soil $\left(I T L_{0}\right)$ and the derived ones $\left(I T L_{10}\right.$ and Fines) 


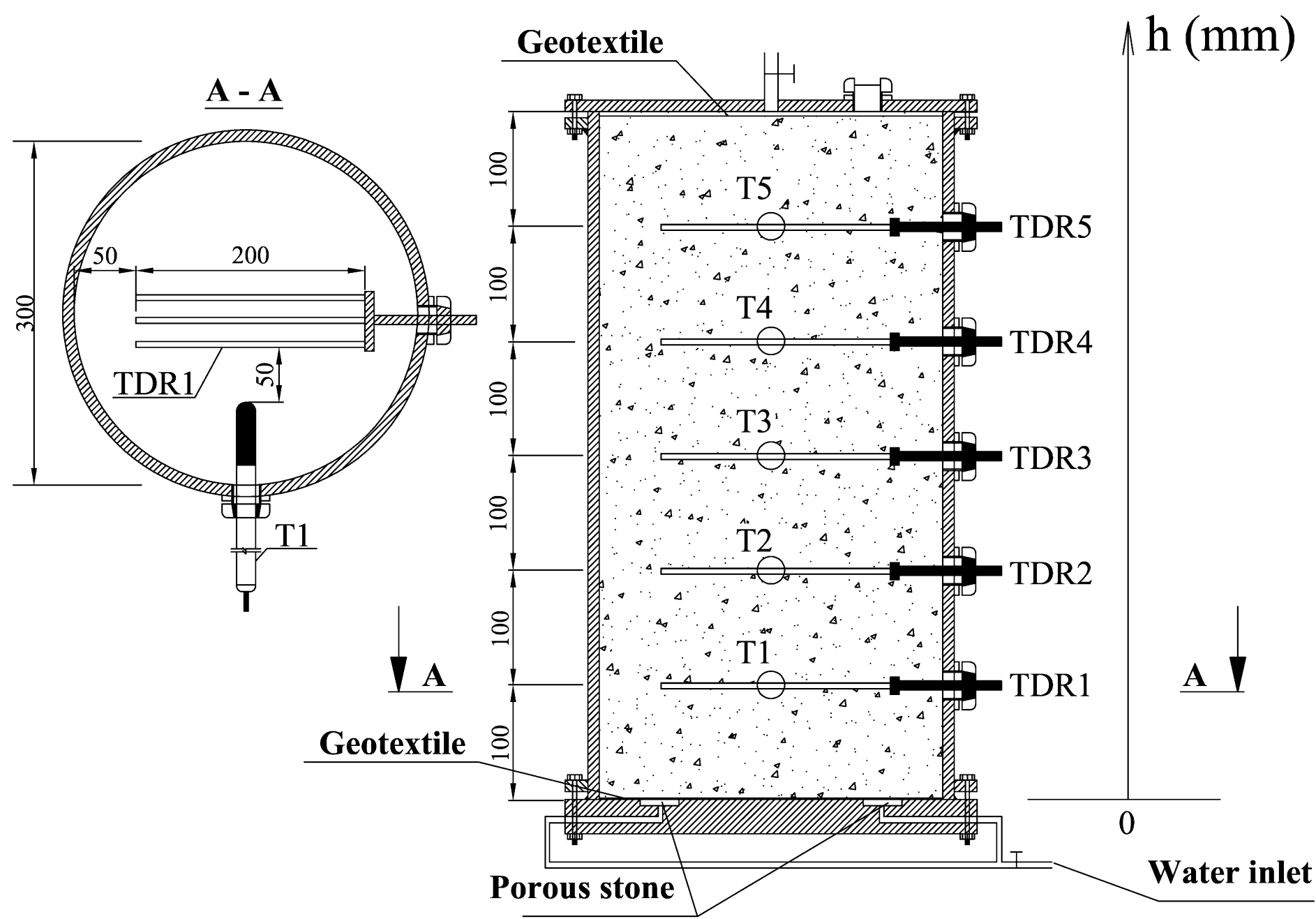

632

633

Fig. 2: Schematic view of the large-scale infiltration column 


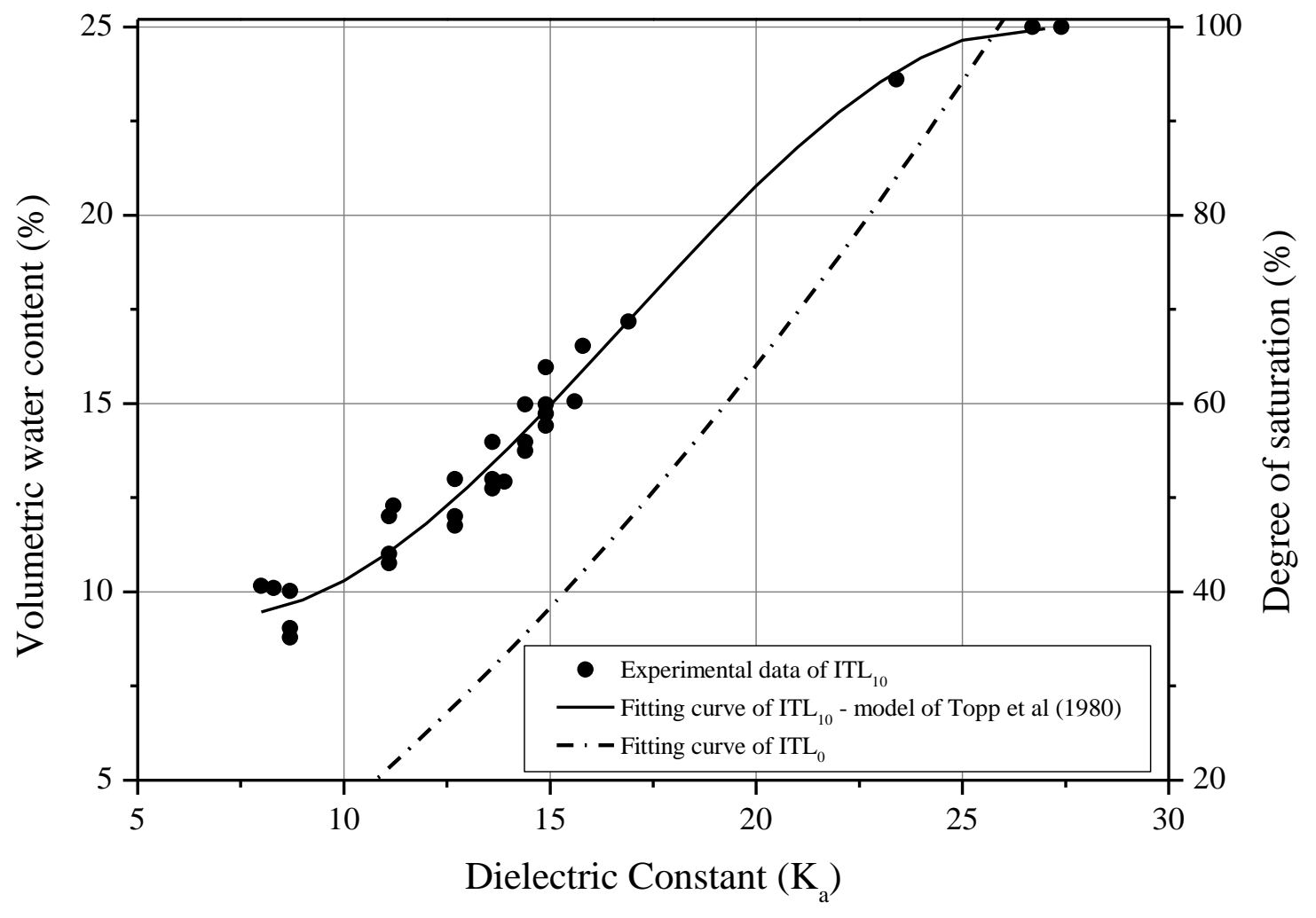

634

635 Fig. 3: Calibration curves of the TDRs used for the $I T L_{10}$ and $I T L_{0}$ specimens

636 


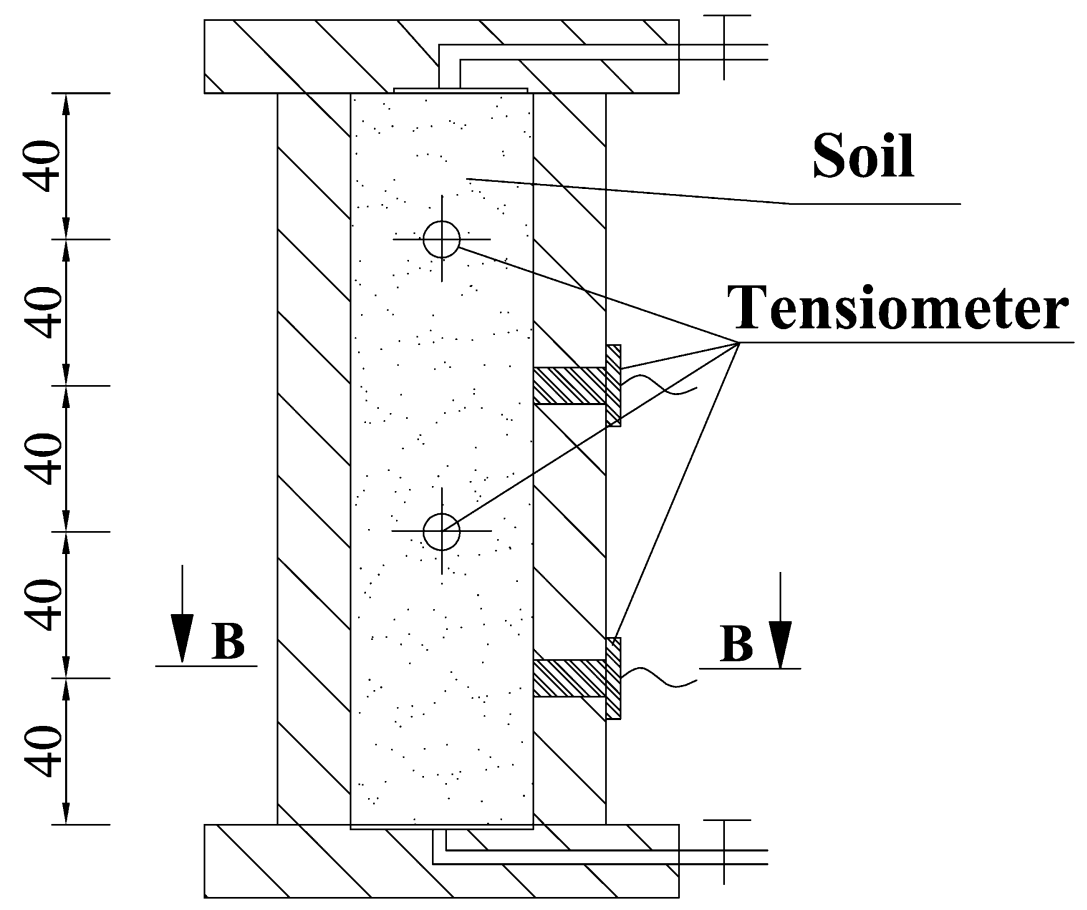

B-B

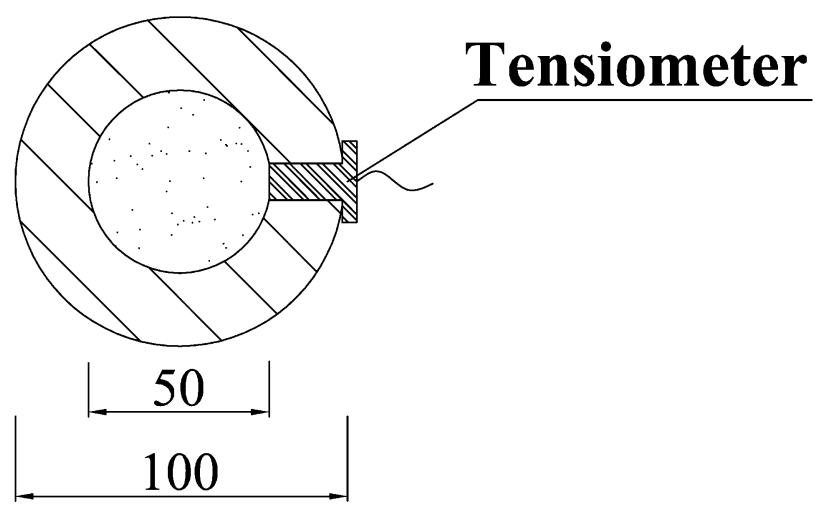

Fig. 4: Schematic view of the small-scale infiltration column 

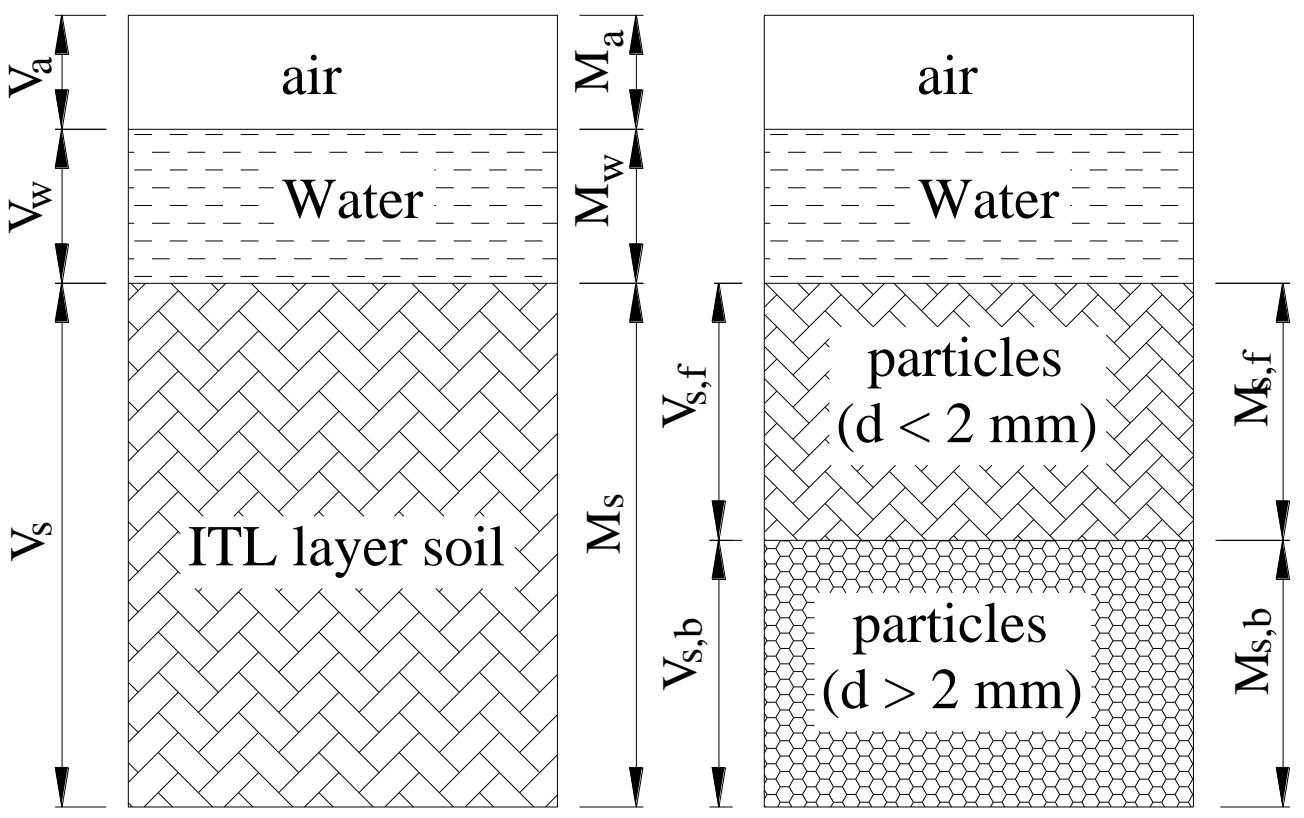

640 Fig. 5: Components of the unsaturated interlayer soil

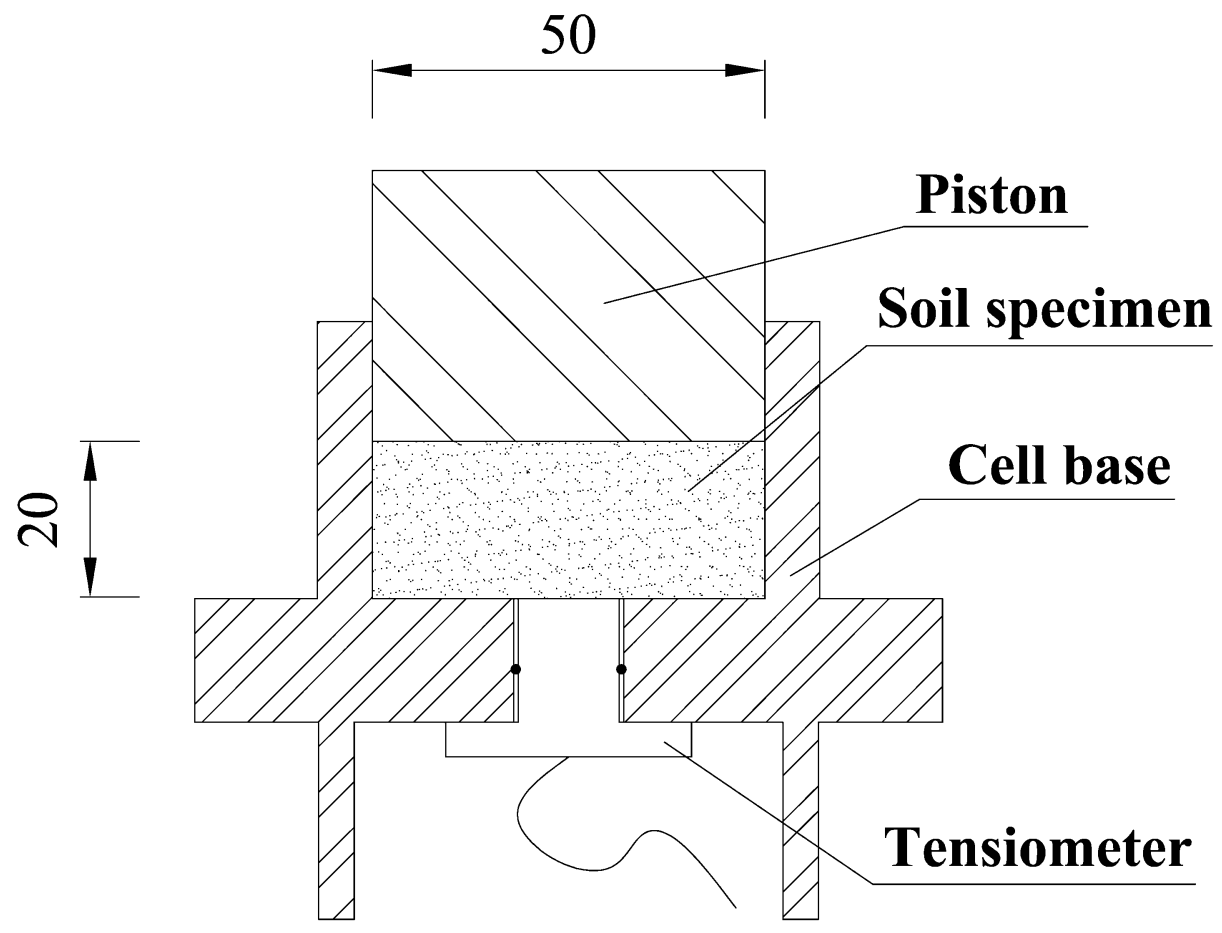

641

642 Fig. 6: Device for determining the WRC of Fines 

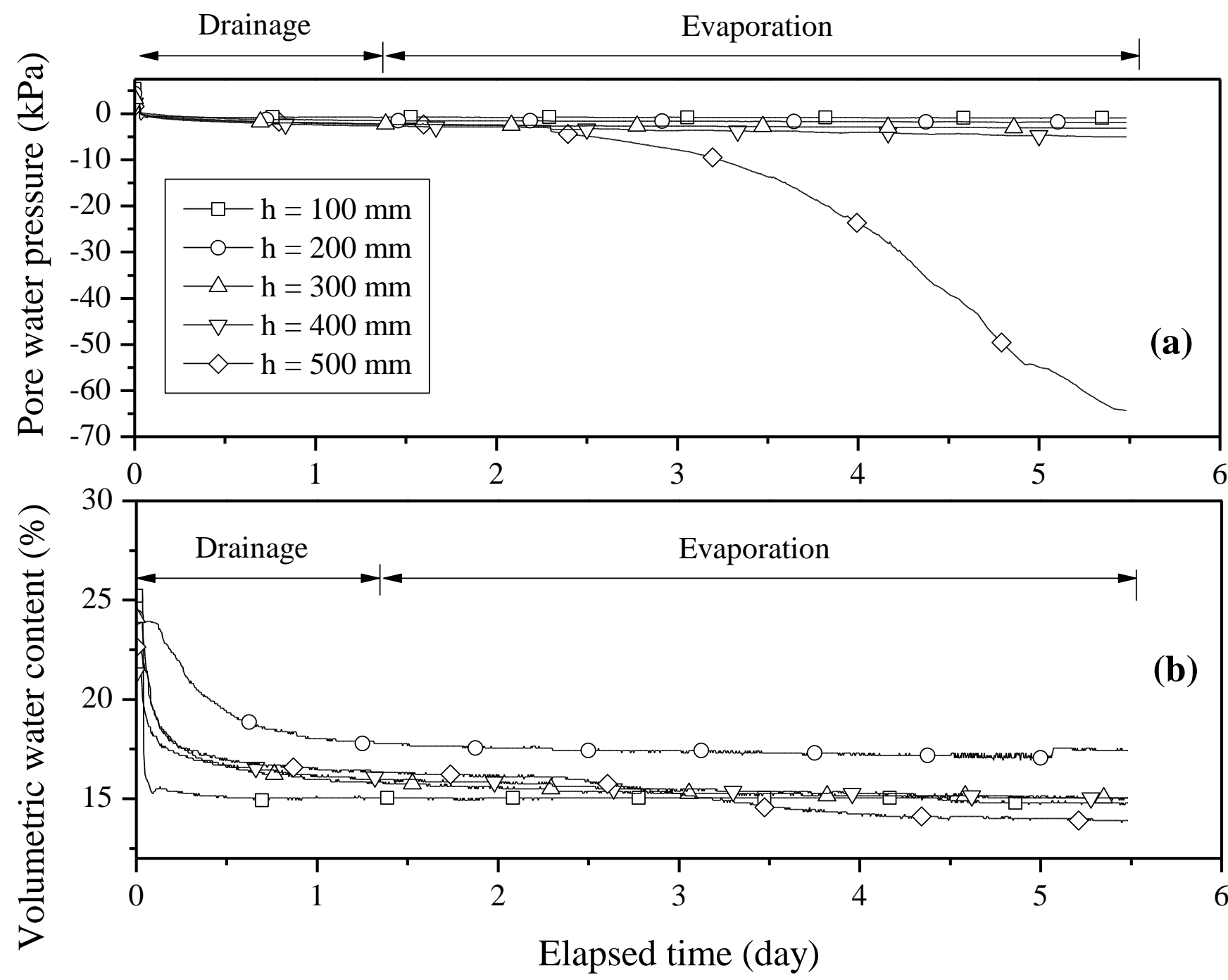

644 Fig. 7: Test on $I T L_{10}$ : pore water pressure and volumetric water content evolutions during Drainage 1 and 645 Evaporation 1 

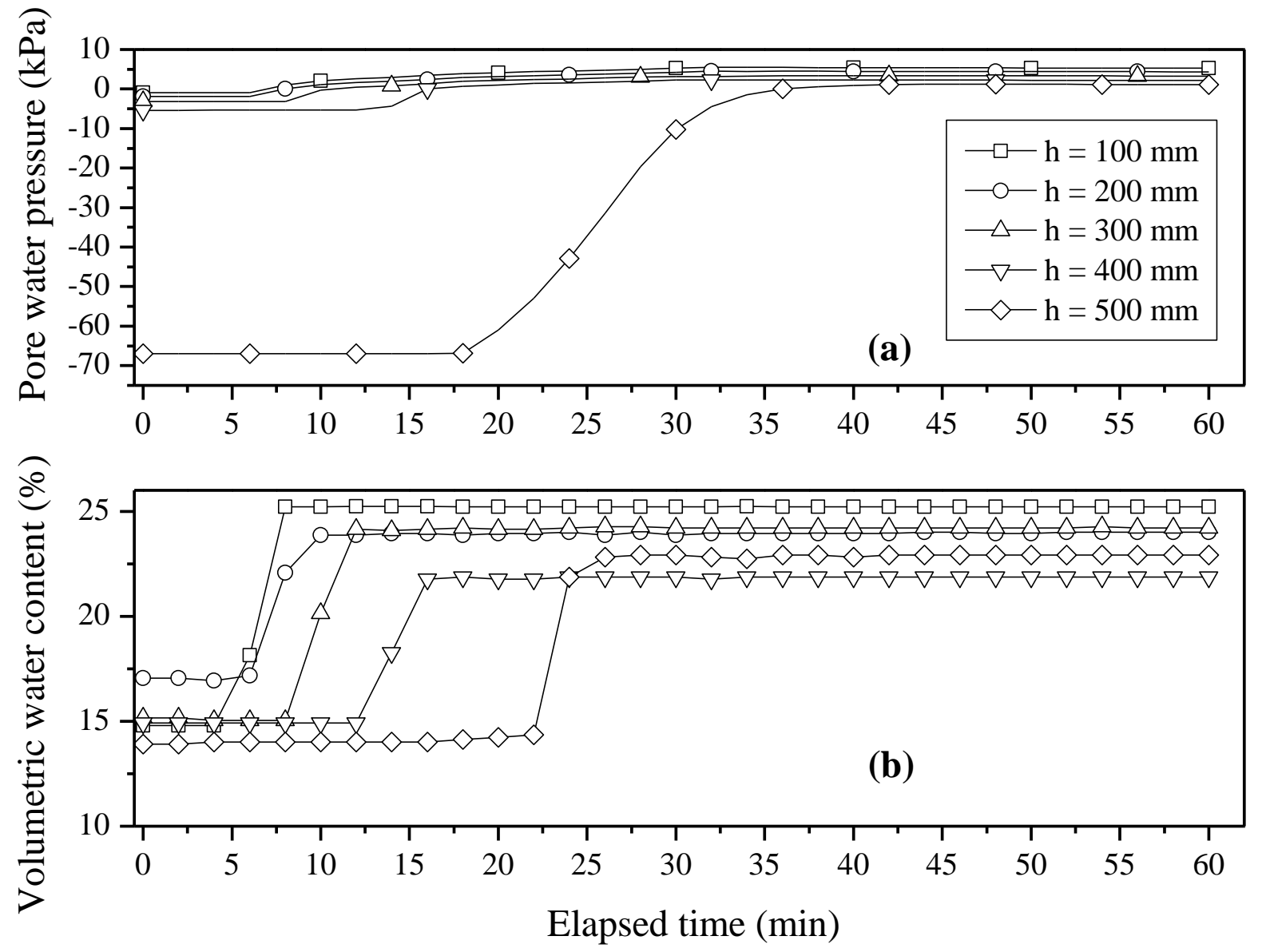

Fig. 8: Test on $I T L_{10}$ : pore water pressure and volumetric water content evolutions in Saturation 2 

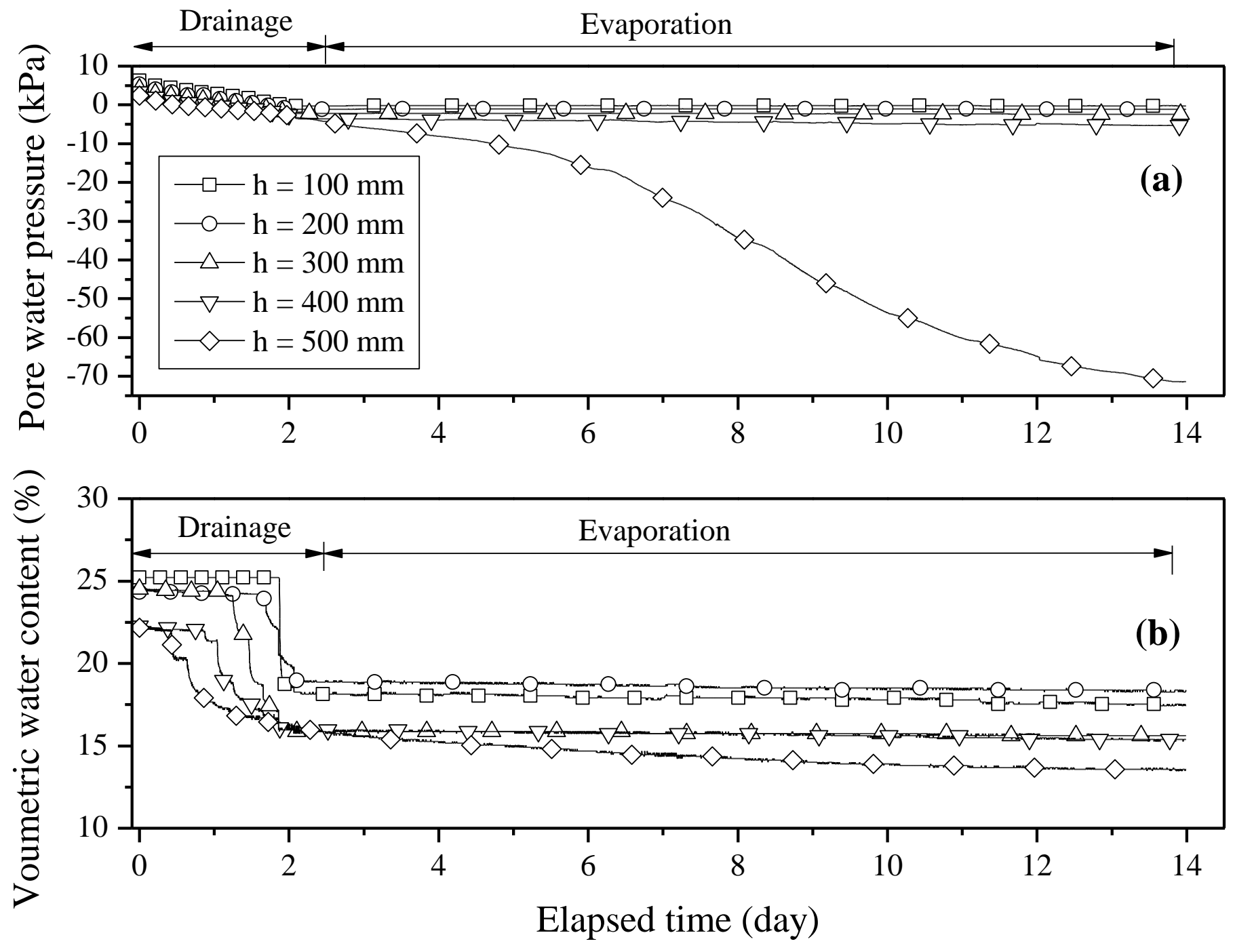

650 Fig. 9: Test on $I T L_{10}$ : pore water pressure and volumetric water content evolutions during Drainage 2 and 651 Evaporation 2 


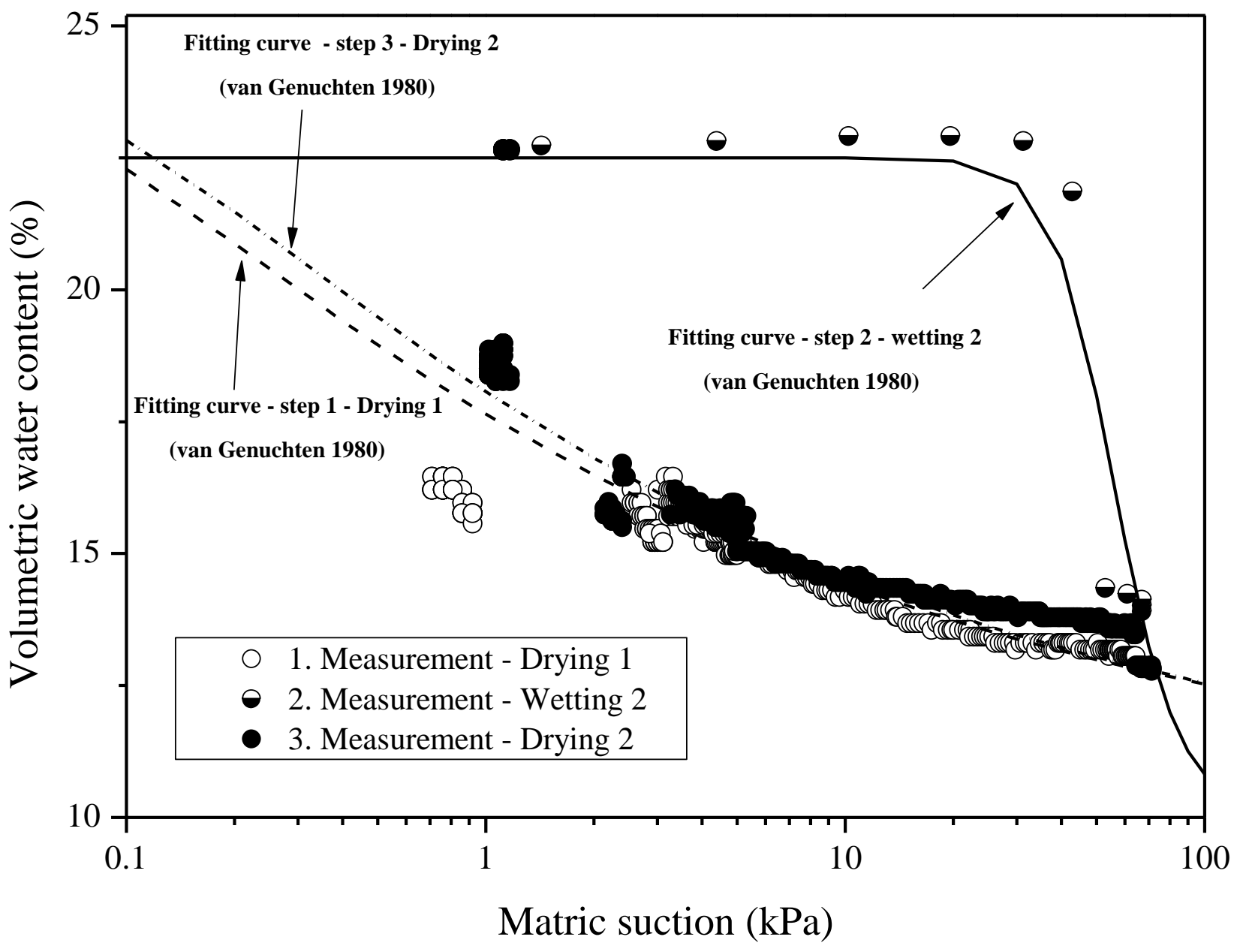

653 Fig. 10: WRC of $I T L_{10}$ with fitting curves using the van Genuchten's model (1980) 


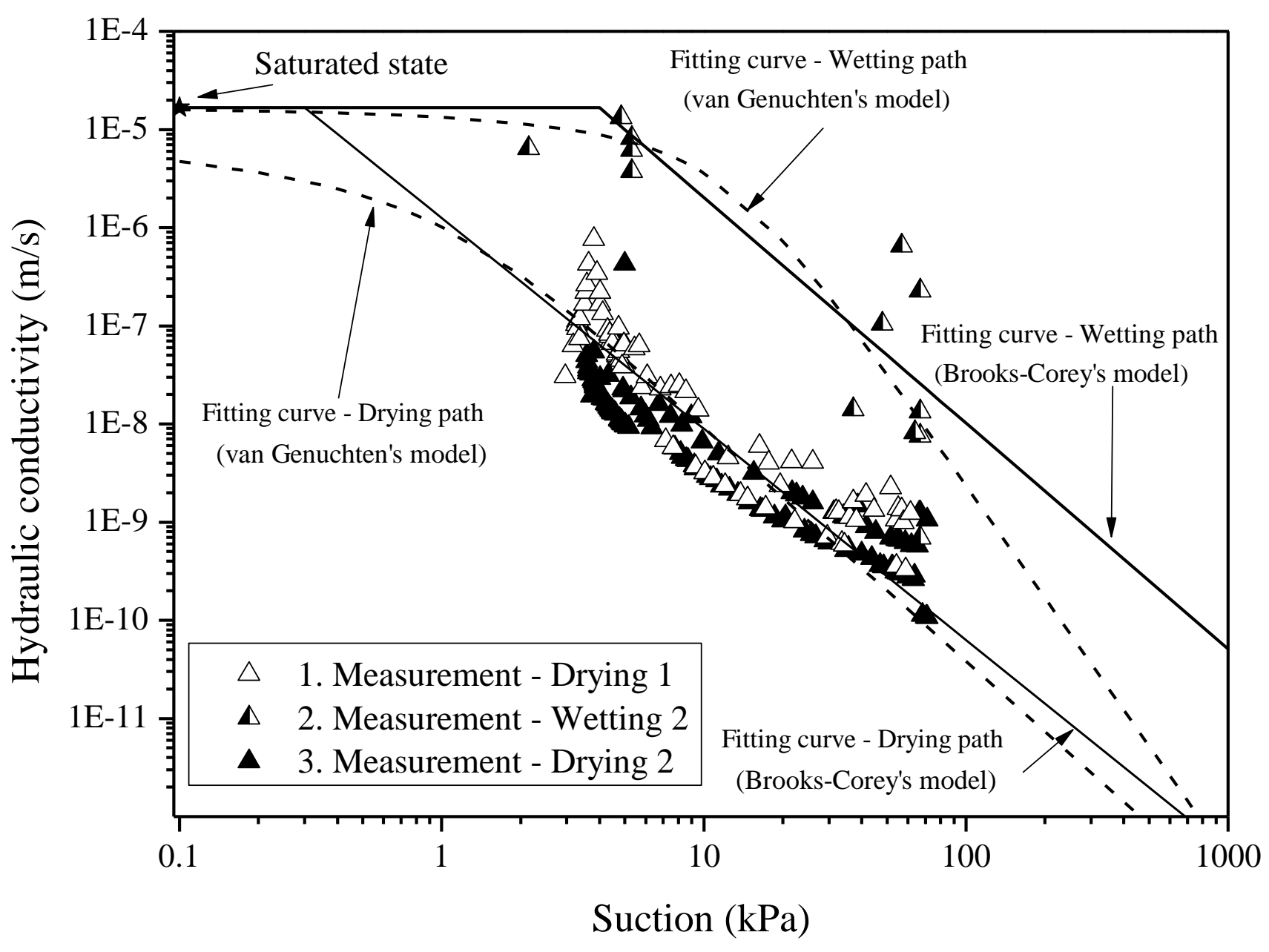

656 Fig. 11: Hydraulic conductivity of $I T L_{10}$ obtained with drying-wetting cycles 


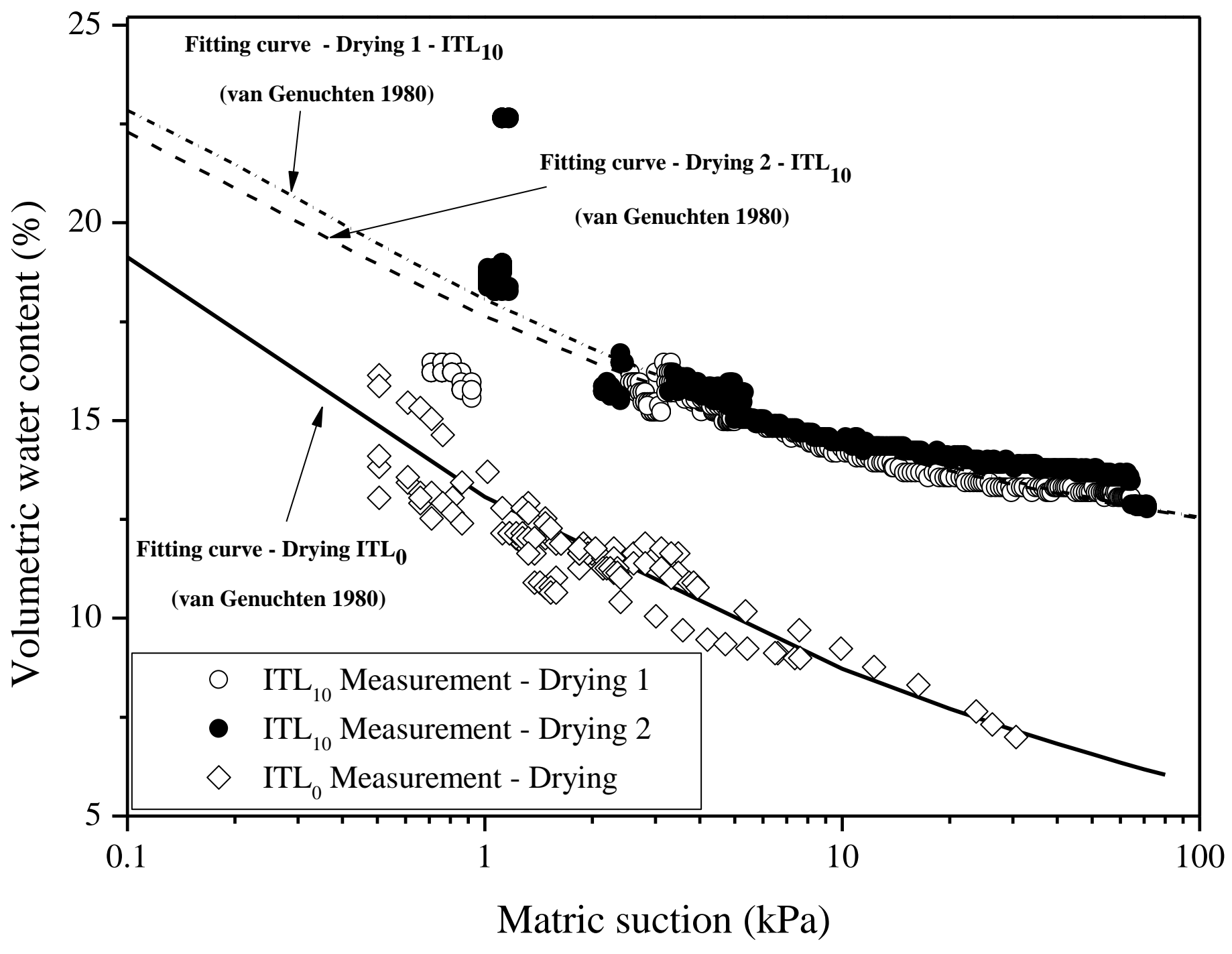

658 Fig. 12: Comparison of SWRC between $I T L_{0}$ and $I T L_{10}$

659

660 


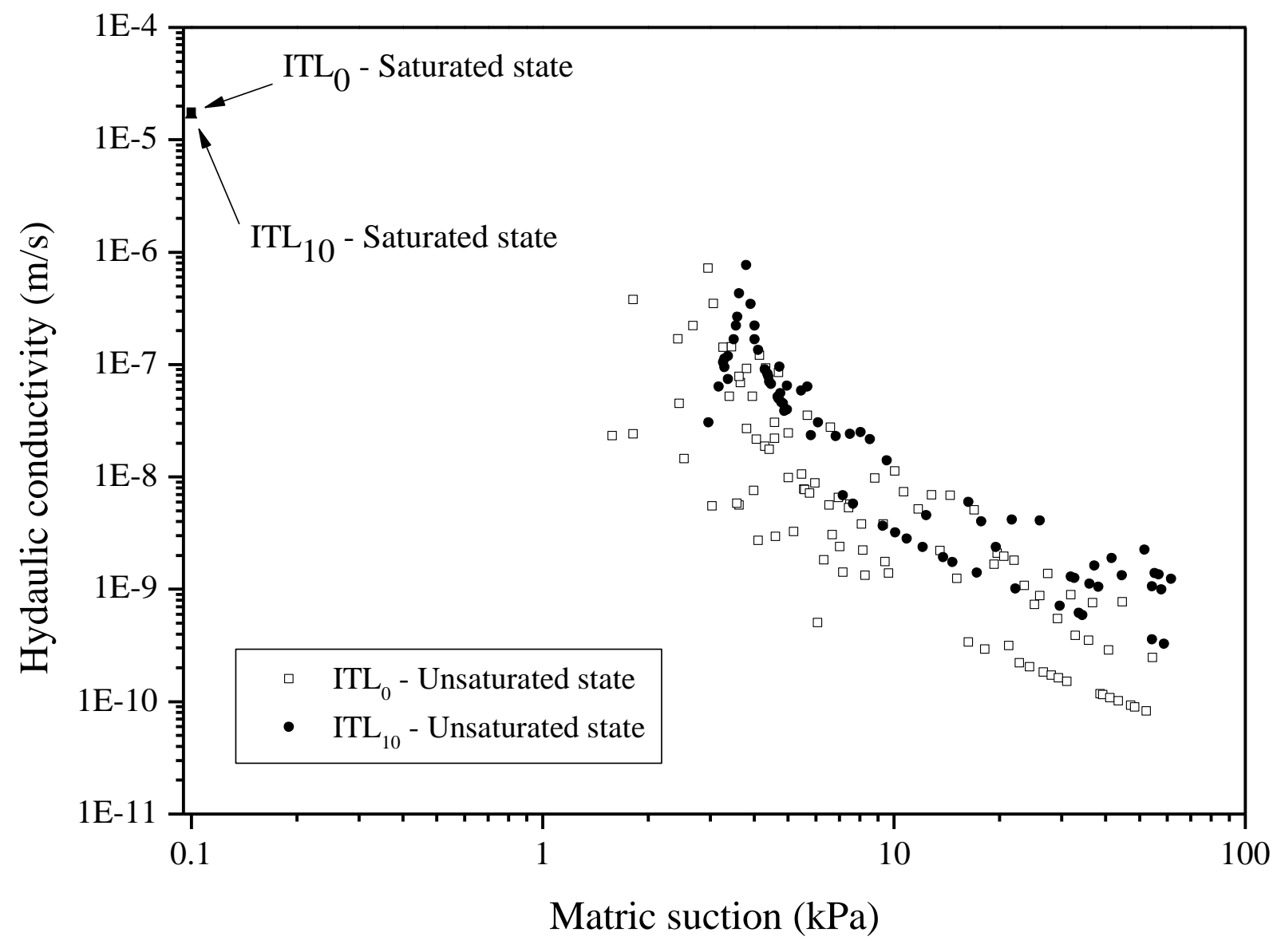

662 Fig. 13: Comparison of hydraulic conductivity between $I T L_{0}$ and $I T L_{10}$ 


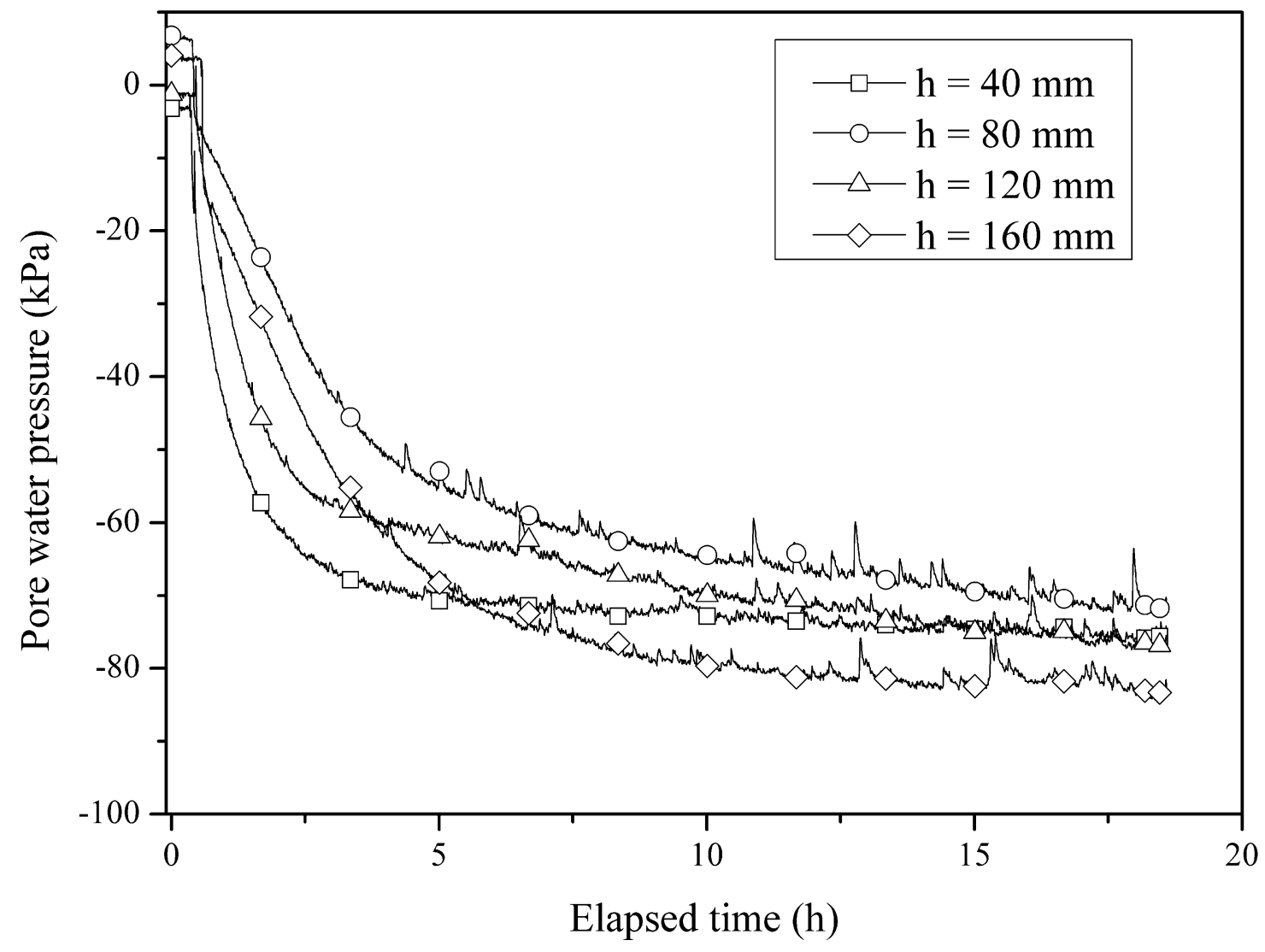

664

Fig. 14: Test on Fines: suction stabilization after the installation of tensiometers

665 


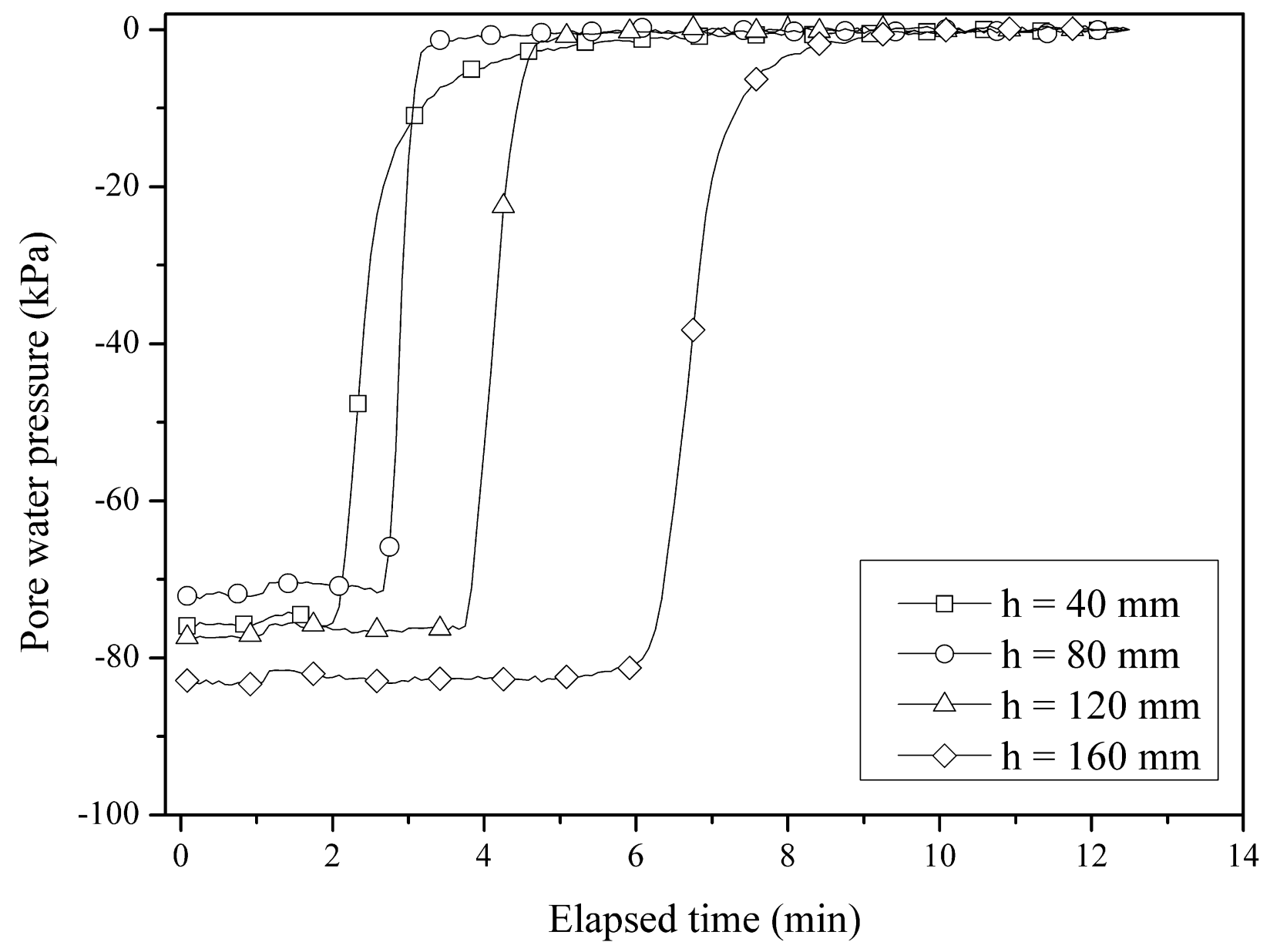

666

Fig. 15: Test on Fines: suction evolutions during Saturation 1 


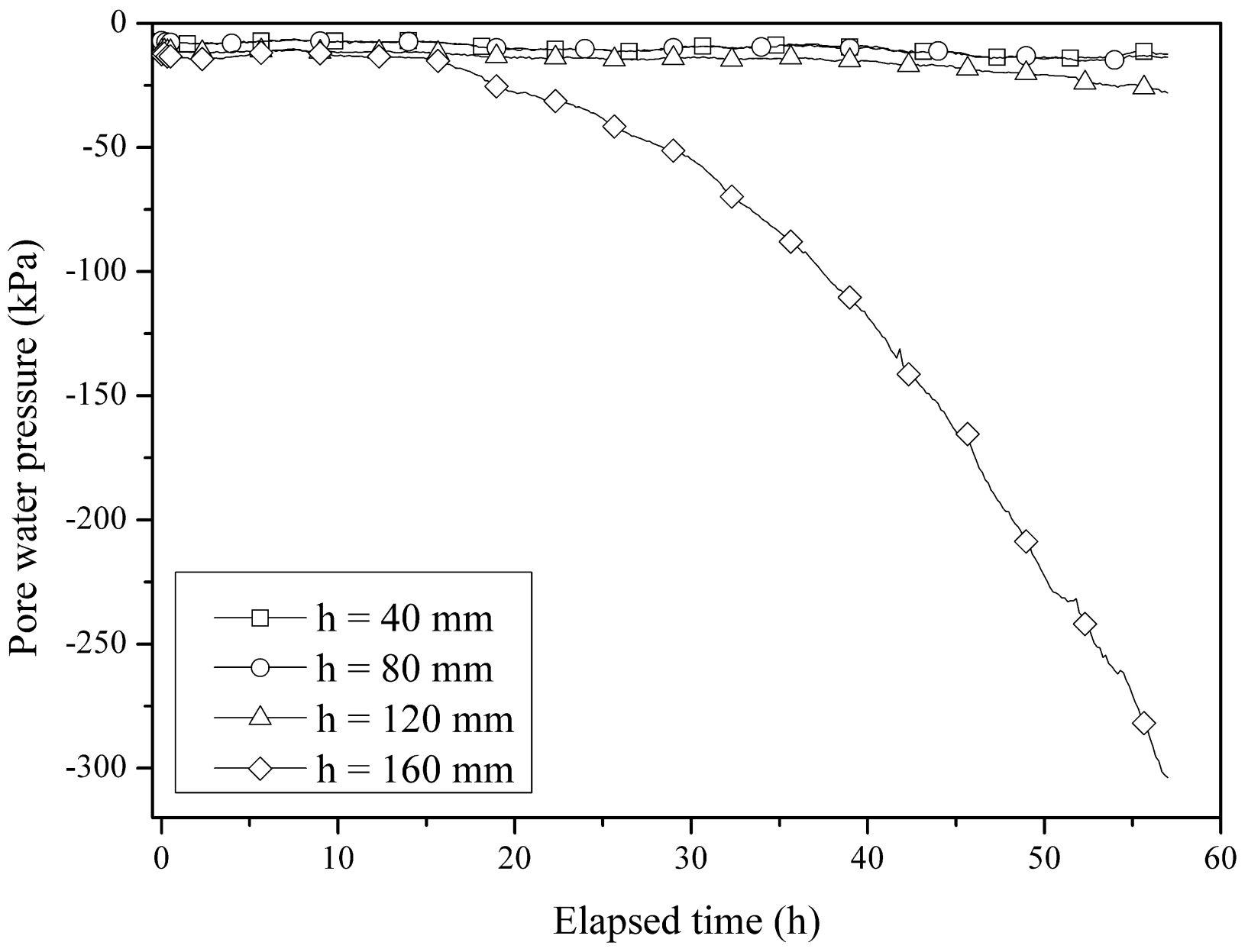

668

Fig. 16: Test on Fines: suction evolutions during Evaporation 1 


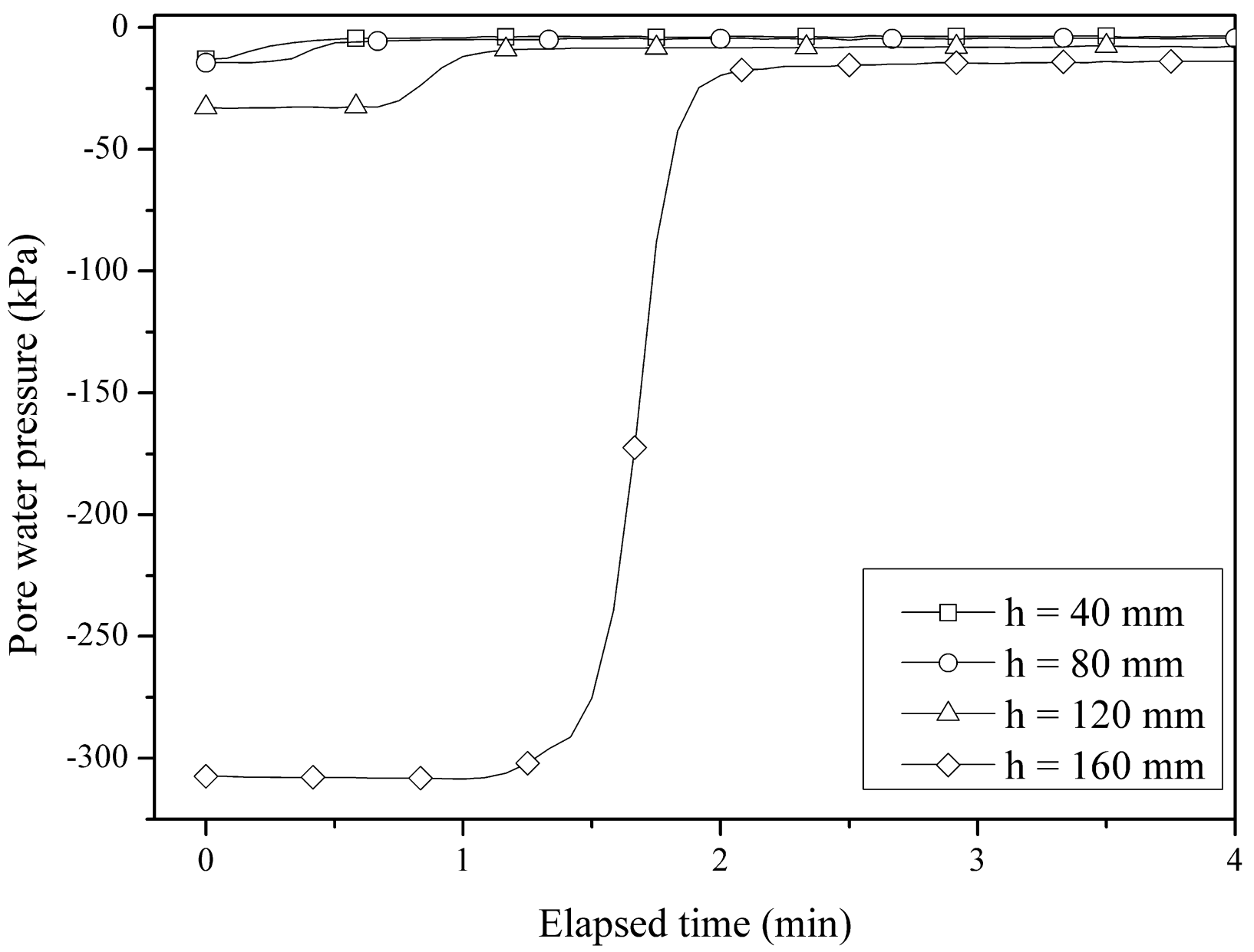

670

671 Fig. 17: Test on Fines: suction evolutions during Saturation 2

672 


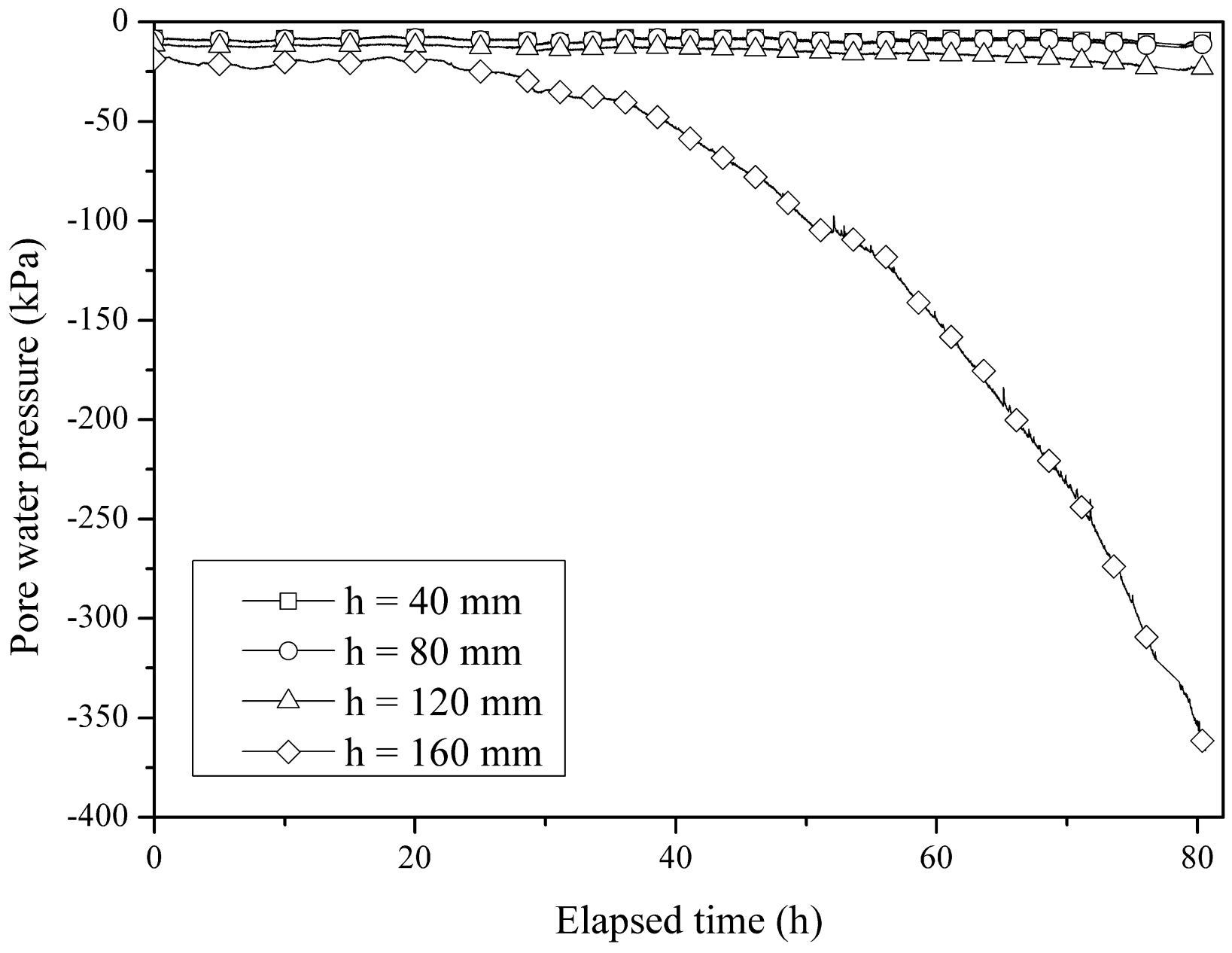

673

674 Fig. 18: Test on Fines: suction evolutions during Evaporation 2 

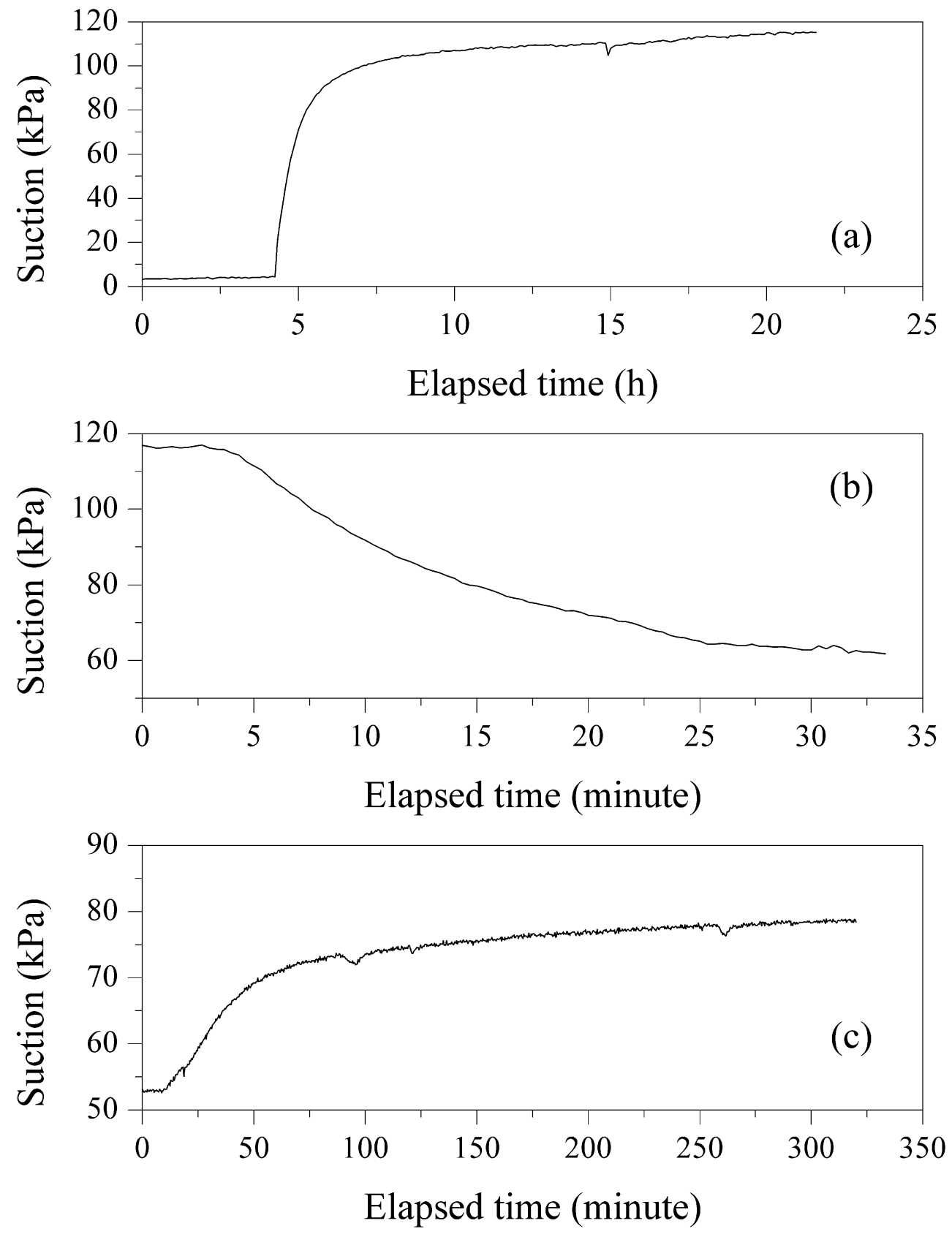

676 Fig. 19: Stabilization of suction during the SWRC determination. (a) initial stabilization after tensiometer 677 installation, (b) a wetting stage, (c) a drying stage 

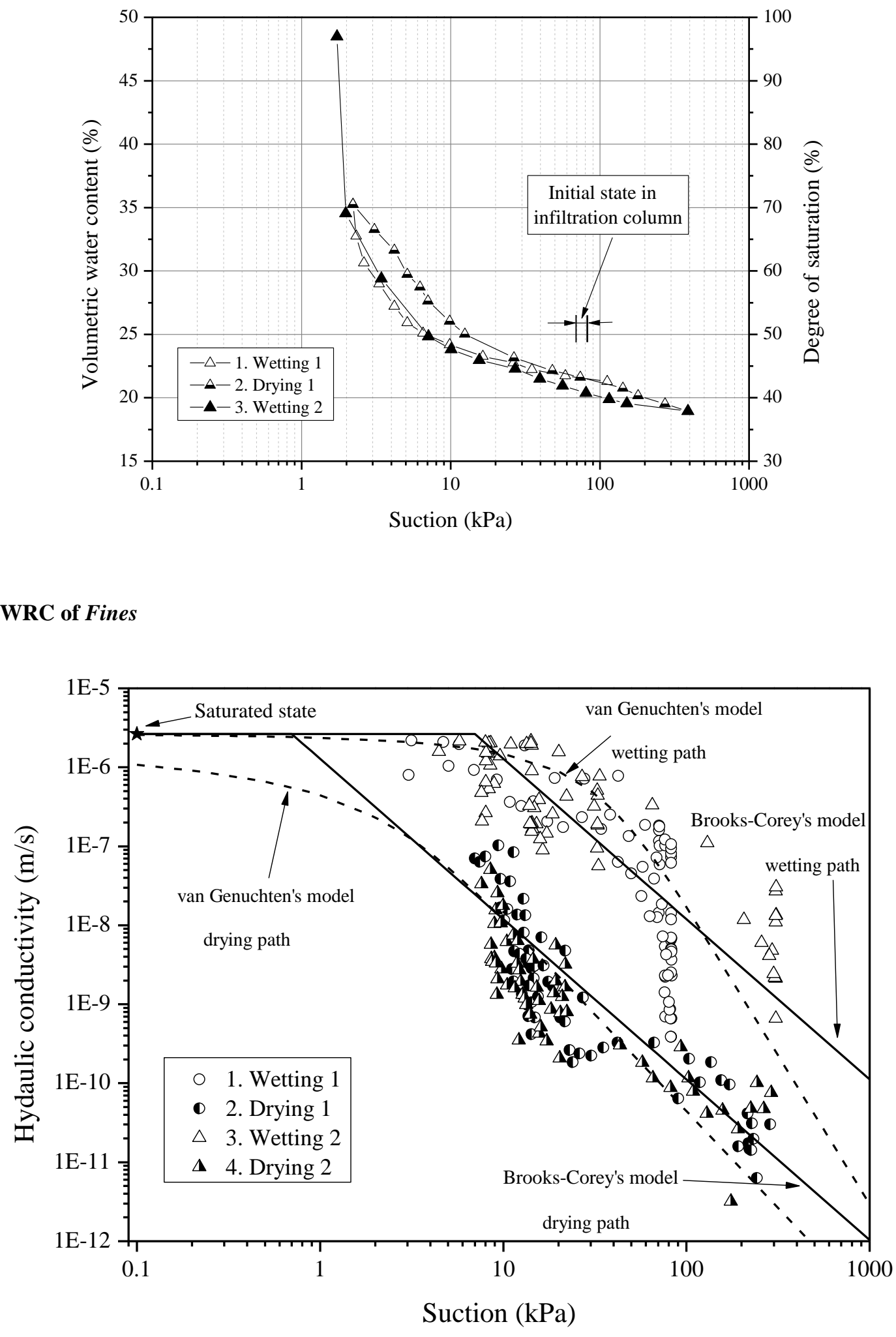


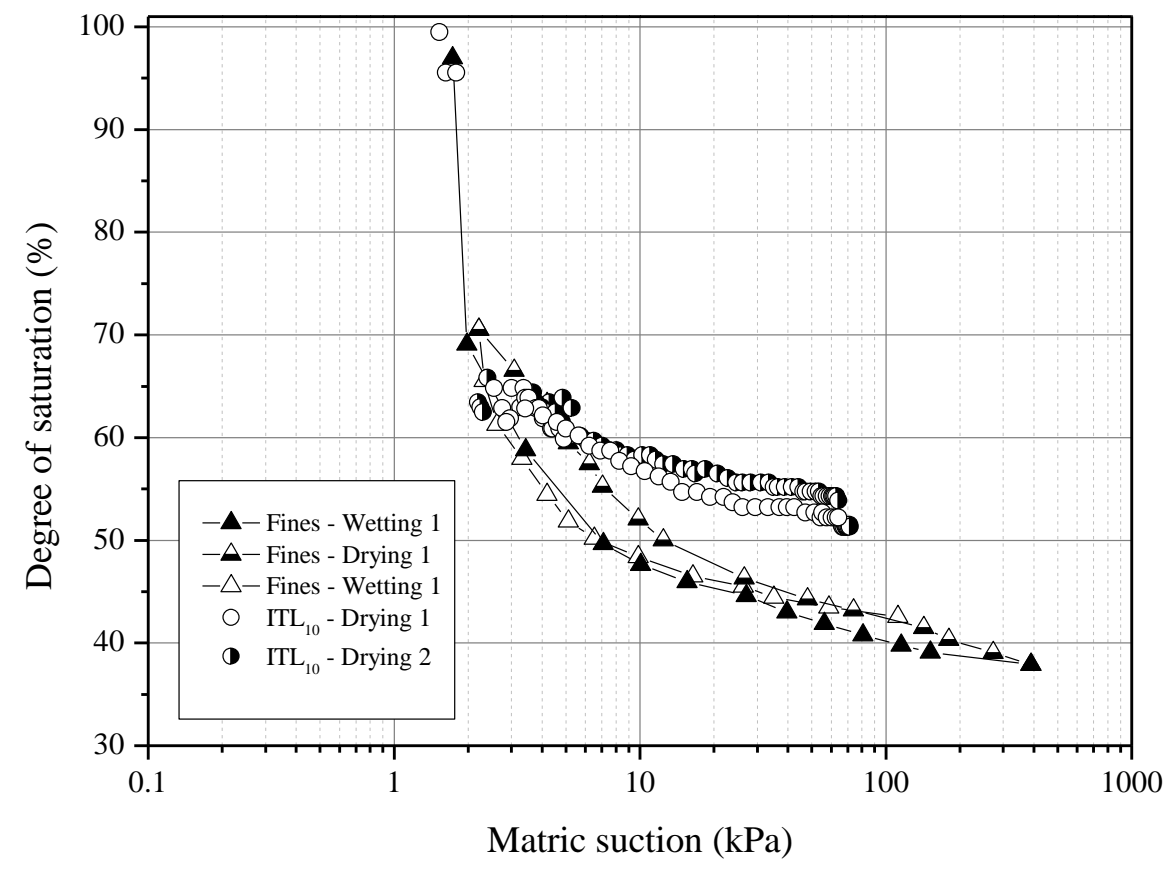

683 Fig. 22: Comparison of SWRC between $I T L_{10}$ and Fines

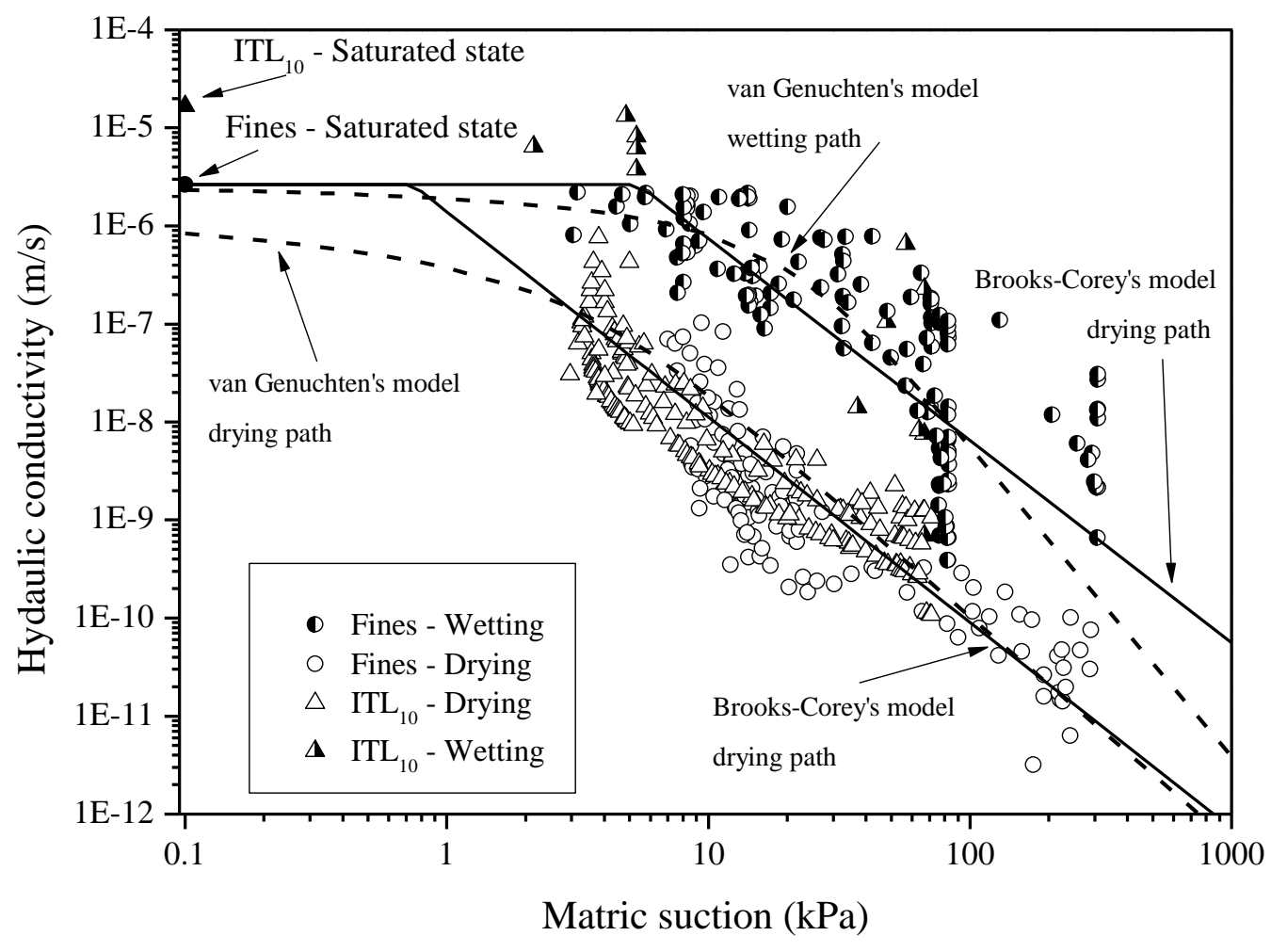

